\title{
Mental Disabilities and DUTy in NeGLigenCE LAW: WILL NEUROSCIENCE REFORM TORT DOCTRINE?
}

\author{
Jean Macchiaroli Eggen* \\ (C) 2015
}

"There is no doubt that in many cases a man may be insane, and yet perfectly capable of taking the precautions, and of being influenced by the motives, which the circumstances demand. But if insanity of a pronounced type exists, manifestly incapacitating the sufferer from complying with the rule which he has broken, good sense would require it to be admitted as an excuse."

Oliver Wendell Holmes, $1881^{1}$

I. INTRODUCTION 593 II. THE BASICS OF MENTAL DISABILITIES IN TORT

LAW 597

A. Intentional Torts. 598

B. The Law of Negligence. 602

C. Judicial Exceptions to the Bifurcated Rule 613 III. MENTAL DISABILITY IN TORT DOCTRINE: IS THERE A ROLE FOR NEUROSCIENCE? 617

A. A Very Brief Look at the Advantages and Weaknesses of Functional Neuroimaging. 618

B. Stigma and Stereotypes 627

C. Is Tort Law Ready for Neuroscience?: Revisiting the

Policies of the Bifurcated Rule.... 629

** Distinguished Professor of Law, Widener University - Delaware Law School. The author wishes to thank Dean Andrew Klein and Professors Nicolas Terry and Jennifer Drobac of the Robert H. McKinney School of Law of Indiana University, Professor Tracy Gunter of Indiana University School of Medicine, and the many others involved in the planning of the symposium on "Neuroscience and Law: Injury, Capacity and Illness" for bringing her into the fold of the neurolaw community and for providing a stimulating environment for the interdisciplinary exchange of ideas. The author also wishes to thank Holly Frey for her research assistance.

1 Oliver Wendell Holmes, The Common LaW 109 (1881). 
IV. THE EVIDENTIARY CHALLENGES OF APPLYING NEUROSCIENCE TO TORT LAW

A. The Intersection of Law and Science.

B. Neuroethics and the Search for Truth in the Courtroom

C. Is Neuroscience Ready for Tort Law?: Moving from the

Laboratory to the Courtroom ..........................................638 638

V. A MODEST PROPOSAL WITH CAVEATS .................. 643

A. A Framework for Commencing the Discourse .......... 644

1. The duty rule for adults with mental disabilities

should be consistent with the rule for physical

disabilities.

2. The unified subjective rule should expressly recognize that many mental disabilities are organic in nature. 644 3. To be considered in determining liability, the mental disability must be "significant and objectively verifiable.".

4. All expert evidence of mental disabilities, including all neuroscience evidence, will be subject to the applicable rules of evidence.

5. There should be no new defense for persons with mental disabilities.

6. Existing privileges and defenses that involve mental

conditions should remain in effect.....

B. Some Caveats

1. Courts should be cognizant of the limitations of the technology.

2. Courts should take care to apply the same

evidentiary scrutiny to neuroscientific evidence as to other expert evidence, no more and no less.

VI. CONCLUSION 


\section{INTRODUCTION}

Tort doctrine is replete with mental states, some of which represent arbitrary policy decisions on complex matters, including mental disabilities. ${ }^{2}$ The traditional premise for tort liability is fault, or "blameworthiness" in the words of Holmes, ${ }^{3}$ and the broadest categories of tortsintentional torts and negligence-define fault in the context of mental states. Thus, for a defendant to be at fault, the defendant must make a decision to act in a certain manner that creates a specific risk of harm to the plaintiff's person or property. Generally, tort doctrine imposes the same set of rules on all actors, but allows subjective consideration of certain characteristics of the actor, such as physical disabilities or the age of a child, to be applied when determining liability. One conspicuous exception is mental disabilities in negligence law, on which torts doctrine imposes an objective standard, holding persons with mental disabilities to the same duty standard as persons without such disabilities. Some defendants, however, may not have the mental ability to act in a way that constitutes legally cognizable "fault."

Developments in neuroscience 4 over the past two decades have inspired much speculation about the ability of

2 The Americans with Disabilities Act (ADA) defines "disability" as "a physical or mental impairment that substantially limits one or more major life activities of such individual." 42 U.S.C. § 12102(1)(A) (2014). Among the activities the ADA identifies-in a nonexclusive list-as "major life activities" are "learning, reading, concentrating, thinking, [and] communicating." Id. $§ 12102(2)(\mathrm{A})$. This Article will use the term "mental disability" in broadly the same way as the ADA and, unless otherwise indicated, without reference to the specific cause of the mental disability. This Article does not intend, however, to use the term in a way that is consistent in all ways with the ADA and the cases that construe it.

3 See Brown v. Kendall, 60 Mass. (6 Cush.) 292 (1850); Holmes, supra note 1 , at 108 .

4 This article uses the term "neuroscience" for the broad category of brain science, including the technologies of structural and functional neuroimaging. Occasionally, "neuroimaging" or "structural" or "functional" neuroimaging will be used to designate more specific 
neuroscience to identify and understand the brain pathways associated with human behavior and the utility of that information for making normative legal decisions about fault. As a result, neuroscience has become an increasingly seductive adjunct to the law, offering the promise of explaining actors' decisions, actions, emotions, moral positions, and motivations. Tort law, based as it is on human behavior, is an especially fertile area for interest in these developments. Commentators have warned, however, that the science is nascent, its utility problematic, and its application to the law conjectural. ${ }^{5}$ Although advancements in functional neuroimaging have accessed the brain in ways previously unimagined and offered data on activity in the brain in real time, it is unclear at present whether neuroscience will be capable of fulfilling the inflated promises. What is apparent, however, is that notwithstanding these concerns neuroscience may have much to offer tort law, both in individual cases and in the reform of tort doctrine.

The criminal justice system has begun to take notice of neuroscience in all aspects of the adjudicatory process, from pre-trial through post-conviction, ${ }^{6}$ but the civil justice system has been slower to embrace the possibilities of neuroscience. The U.S. Supreme Court in several recent

technologies. See generally infra notes 104-09 and accompanying text (identifying the technologies).

5 See, e.g., Owen D. Jones et al., Law and Neuroscience, $33 \mathrm{~J}$. NeUROSCI. 17624, 17624-25 (2013) (stating that some of the possible uses of neuroscience in the law are "more theoretical than current," but recognizing that neuroscience can make important contributions to the law). One writer has stated that using neuroimaging to help resolve legal issues may allow courts "to directly inspect people's brains and to bypass the filter of their own and other people's agendas." Nicole A. Vincent, Neuroimaging and Responsibility Assessments, 4 NEUROETHiCs 35, 38 (2011).

6 See Scott T. Grafton, Has Neuroscience Already Appeared in the Courtroom?, in A Judge's Guide To Neuroscience: A Concise InTRODUCTION 54, 55 (Law \& Neuroscience Project \& SAGE Ctr. for the Study of Mind 2011). Grafton has referred to the introduction of mitigating evidence in capital cases as the "front line" for testing neuroscience evidence in the courtroom because of the courts' willingness to admit more evidence for that purpose. See id. 
decisions has taken note of advancements in neuroscience to shape criminal law doctrine on the punishment of juveniles. The Court referred to the developmental immaturity of the brains of juveniles in these decisions. ${ }^{7}$ In contrast, tort law follows a splintered and inconsistent approach to mental states, including mental disabilities. Although mental disability is a factor in determining the liability of adults and children for intentional torts, it is only considered for children under the law of negligence. Furthermore, negligence law imposes a bifurcated rule for adult tortfeasors, according to which physical disabilities of adults are considered in determining liability, but mental disabilities are ignored. This rule continues to be the majority rule despite regular criticism over many decades, not because it is a good rule but because it is a familiar and convenient rule. As a result, there is a longstanding tradition of mixed messages in tort law, created by an illogical set of policy-laden rules. For decades commentators have noted that the bifurcated rule does not comport with modern medical understanding and psychiatric views of mental illness and other mental disabilities. ${ }^{8}$ Neuroscience adds a new dimension to these voices, as new developments in neuroimaging may provide greater insight into the relationship between organic brain function and human behavior. Developments in neuroscience invite a fresh examination of the bifurcated

7 See, e.g., Alabama v. Miller, 132 U.S. 2455 (2012). The Court noted that "brain science continues to show fundamental differences between juvenile and adult minds," and held that mandatory life imprisonment without parole for persons under the age of eighteen was unconstitutional. Id. at 2464-65; see also Roper v. Simmons, 543 U.S. 551,578 (2005) (referencing neuroscientific studies and holding that the death penalty for persons under the age of eighteen at the time of the capital crime is unconstitutional).

8 See, e.g., Robert M. Ague, Jr., The Liability of Insane Persons in Tort Actions, 60 Dick. L. REV. 211 (1956); William B. Hornblower, Insanity and the Law of Negligence, 5 CoLUM. L. REV. 278 (1905); Henry J.F. Korrell, The Liability of Mentally Disabled Tort Defendants, 19 L. \& Psychology Rev. 1 (1995); David E. Seidelson, Reasonable Expectations and Subjective Standards in Negligence Law: The Minor, the Mentally Impaired, and the Mentally Incompetent, 50 GEO. WASH. L. REV. 17 (1981). 
rule to determine whether an alternative rule better serves parties and society in general.

Tort law is entrenched in the tradition of the common law and has been slow to reflect contemporary advancements and social patterns. Thus, resistance to change is to be expected, and change can only come about jurisdiction by jurisdiction and issue by issue. This Article takes the position that it is time to begin a reasoned discourse about the possibility of integrating new developments in neuroscience into tort law in ways that can ameliorate, augment, and ultimately transform tort doctrine. The bifurcated rule presents a logical point to initiate this discourse. As neuroscience provides increasing information about the basis of mental illness and other causes of mental disabilities, the traditional bifurcated rule has become an anachronism. Ongoing advancements in neuroscience may have the ability to clarify the factual bases underlying the traditional rule and determine whether the rule continues to be justified. In this way, neuroscience may be a useful tool to influence the development of substantive tort doctrine. ${ }^{9}$

This Article begins in Part II with an overview of the role of mental states in intentional torts and negligence. This section first discusses the basic asymmetry between intentional torts and negligence, with intentional torts employing a subjective mental state rule for all adults and children, but with the law of negligence imposing an objective rule for adults with mental disabilities while maintaining a subjective rule for children. This section proceeds to focus on the bifurcated rule in negligence, which establishes a subjective rule for persons with physical disabilities but an objective rule for those with mental disabilities. Attention is given to some judicial exceptions that suggest a path toward transforming the traditional

9 For a broad overview of the tort doctrines, the science, and the potential uses of and likely challenges to the introduction of neuroscience in tort cases, see Jean Macchiaroli Eggen \& Eric J. Laury, Toward a Neuroscience Model of Tort Law: How Functional Neuroimaging Will Transform Tort Doctrine, 13 Colum. SCI. \& TECH. L. REV. 235 (2012). 
doctrine. Part III then examines the role that neuroscience may be able to play in understanding mental disabilities and, ultimately, duty in tort law. Part IV takes a closer look at some of the global challenges to using neuroscience in tort actions and as a vehicle for transforming tort doctrine. This part focuses separately on the law-science distinction, the ethical considerations of using neuroscience in the law, and the evidentiary challenges of moving neuroscience into the courtroom. Finally, in Part V this Article offers a modest proposal for understanding how neuroscience may contribute to eliminating the bifurcated rule in tort law. This proposal is intended as a means to initiate a broader discourse about neuroscience and other aspects of tort doctrine. This Article concludes that on balance the bifurcated rule is no longer tenable in the era of neuroscience, and that with appropriate caution neuroscience may play a key role in transforming tort doctrine to allow mental disabilities of all people to be a factor in determining tort liability.

\section{THE BASICS OF MENTAL DISABILITIES IN TORT LAW}

The long-standing rule in tort law has been that a defendant may not rely on his or her insanity or diminished mental state to escape liability in tort. ${ }^{10}$ In the early case of Williams v. Hays, the New York Court of Appeals held that "[t]he general rule is that an insane person is just as responsible for his torts as a sane person, and the rule applies to all torts," with specific limited exceptions. ${ }^{11}$ This rule, the court said, was grounded in several policies. First, as between two innocent parties, the loss must be borne by

10 The Second Restatement of Torts notes that "[t]he rule that a mentally deficient adult is liable for his torts is an old one, dating back at least to 1616 . . .." Restatement (SECOND) OF TORTS $\S 283 \mathrm{~B}$, cmt. b (1965).

11 Williams v. Hays, 38 N.E. 449, 450 (N.Y. 1894). The court indicated that an exception would apply in torts "in which malice, and therefore intention, actual or imputed, is a necessary ingredient, like libel, slander, and malicious prosecution." Id. 
the person who caused the injury. ${ }^{12}$ Second, public policy favors a rule that will encourage the persons with an interest in the estate of a mentally ill person to take measures to prevent the person from harming others. ${ }^{13}$ And third, such a rule discourages persons from feigning mental illness so as to avoid liability for their tortious conduct. ${ }^{14}$ Although more than a century has transpired since the Williams decision, the basic doctrine has not changed.15 Indeed, both the Second and Third Restatements of Torts reaffirmed its prevalence along with the underlying policy justifications. ${ }^{16}$ While mental disability is not a defense to or excuse from tort liability in a general sense, courts have sometimes allowed mental disabilities to be considered as one factor among many in determining liability for both intentional torts and negligence. The result, however, has been an arbitrary and fragmented set of rules.

\section{A. Intentional Torts}

For intentional torts, a plaintiff must show that the defendant satisfies the requirement of intent, which the Third Restatement of Torts defines as a mental state in which "the person acts with the purpose of producing that consequence; or the person acts knowing that the consequence is substantially certain to result." 17 Both parts of this definition could be in play when the mental ability of the defendant is an issue. The basic rule, which is subjective in nature, incorporates the need to show that the

$12 I d$.

13 Id.

14 Id.

15 See, e.g., Delahanty v. Hinckley, 799 F. Supp. 184, 186 (D.D.C. 1992) ("An insane person is liable for compensatory damages for his torts where express malice or evil intent is not a necessary element of the tort. . . . The primary purpose of such a rule is to compensate the victims for their loss.").

16 See Restatement (Third) of Torts: Liab. FOR Physical AND Emotional HaRM $§ 11$ (2010); Restatement (SECOND) OF TORTS $§ 283 \mathrm{~B}$ (1965).

17 Restatement (ThiRd) of TORTs: Liab. FOR PHYSicAl AND EMOTIONAL HARM $§ 1$ (2010). 
defendant had the mental capability to know that a particular result was substantially certain to occur. A defendant who is mentally ill or otherwise mentally disabled at the time of the tortious act may be held liable, provided that he or she was capable of forming the requisite intent for the particular tort. 18

This rule became ingrained in tort law early. In the 1887 case of McIntyre v. Sholty, the Illinois Supreme Court held that the mentally ill defendant could be liable in tort under the traditional rule, ${ }^{19}$ while acknowledging that criticisms of the rule had some legitimacy. The court relied on the weight of the majority rule and stated: "However justly this doctrine may have been originally subject to criticism, on the grounds of reason and principle, it is now too firmly supported by the weight of authority to be disturbed." 20 The court emphasized that because the remedy in tort is "mere compensation," and not criminal punishment, holding the mentally ill defendant liable would be fair. ${ }^{21}$ The court also relied on the standard public-policy justifications that would be echoed in Williams and in numerous cases for more than a century. ${ }^{22}$

18 This traditional rule dates back (at least) to the case of Weaver v. Ward, (1616) 80 Eng.Rep. 284 (K.B.). See Francis H. Bohlen, Liability in Tort of Infants and Insane Persons, 23 Mich. L. REV. 9, 31-32 (192425).

19 McIntyre v. Sholty, 13 N.E. 239, 240 (Ill. 1887) ("It is well settled that, though a lunatic is not punishable criminally, he is liable in a civil action for any tort he may commit.").

$20 I d$.

21 See id. The court stated: "There certainly can be nothing wrong or unjust in a verdict which merely gives compensation for the actual loss resulting from an injury inflicted by a lunatic." Id.

22 See id.; see also Williams v. Hays, 38 N.E. 449, 450 (N.Y. 1894). These policies included: (1) encouraging family members (i.e. "those interested in his estate") to be vigilant in supervising the mentally ill person; (2) shifting compensation to the person responsible for the injury rather than burdening the innocent injured person; (3) encouraging appropriate guardianship processes for the mentally ill who may pose a danger to others; and (4) discouraging tortfeasors from fabricating symptoms to avoid liability. McIntyre, 13 N.E. at 240; see RESTATEMENT (SECOND) OF TORTS $§ 283 \mathrm{~B} \mathrm{cmt}$. b (1965). 
Because the concept of intent in tort law differs from mens rea in criminal law, the traditional rule may lead to a different result in a tort action than in a criminal prosecution based upon the same incident. This distinction is well-illustrated by Polmatier $v \cdot R u s s,{ }^{23}$ in which the defendant had been charged in a criminal proceeding with the death of his father-in-law, but was adjudicated not guilty by reason of insanity. In the subsequent civil wrongful death action for the torts of assault and battery, the defendant's attorney argued that the defendant had been incapable of forming the requisite intent to commit the intentional torts alleged. ${ }^{24}$ The evidence in both the criminal and civil actions showed that the defendant had been suffering from severe paranoid schizophrenia at the time of the incident. ${ }^{25}$ The Connecticut Supreme Court applied the traditional subjective rule for intentional torts and held that the record demonstrated sufficient evidence of intent for the defendant to be held liable under the basic rule, stating that "it is not necessary for a defendant's reasons and motives for forming his intention to be rational in order for him to have the intent to invade the interests of another." 26 The court so ruled notwithstanding the evidence that the defendant had offered various and conflicting irrational reasons for his attack on the decedent. ${ }^{27}$ As cases such as Polmatier demonstrate-and the persistence of the traditional rule in the Restatements of Torts confirms - the majority rule has held fast.

The same rule of intent applies to children. The frequently studied case of Garratt $v$. Dailey ${ }^{28}$ illustrates this rule as it applied to a five-year-old child who had moved a lawn chair just at the moment when the plaintiff attempted

23537 A.2d 468 (Conn. 1988).

24 Id. at 469.

25 Id.

26 Id. at 473.

27 See id. at 472. The court emphasized that the evidence showed that the defendant had made statements to law enforcement and medical authorities "that he intended to punish Polmatier and to kill him," thereby establishing the ability to formulate the intent to commit the torts of assault and battery. Id. at 473 .

28 Garratt v. Dailey, 279 P.2d 1091 (Wash. 1955). 
to sit on it. As a result, the plaintiff suffered serious injuries and brought a battery action against the child defendant. The court defined the main issue in the case as whether the defendant knew with substantial certainty that the plaintiff had been in the act of sitting at the time he moved the chair, thereby having the requisite knowledge that the plaintiff would make contact with the ground. 29 The court emphasized that "[t]he only circumstance where [the defendant's] age is of any consequence is in determining what he knew, and there his experience, capacity, and understanding are of course material." 30 Thus, a subjective standard is routinely applied to children in intentional tort cases.

The consent privilege may invoke similar issues when the plaintiff argues that he or she was incapable of consenting to an act because of a mental disability. A valid defense of consent has the effect of negating the intent of the defendant to commit the intentional tort. ${ }^{31}$ As a general rule, for the plaintiff's consent to bar liability for intentional torts, the plaintiff must only have consented to the act. ${ }^{32}$ No requirement exists that the plaintiff consent to the resulting harm. ${ }^{33}$ The mental disability or other incapacity of the plaintiff may render consent ineffective, however. The rules of consent for both adults and children who lack capacity, including intoxicated persons, are similar to the subjective rule for intent. Thus, if the plaintiff was capable of understanding the act to which he or she consented and its likely consequences, consent will be legally effective. ${ }^{34}$

\footnotetext{
29 Id. at 1093.

30 Id. at 1094. Because the trial court's findings were not clear, the court remanded for clarification of the findings. Id.

31 See DAN B. DobBs ET AL., DobBs' LAW Of TorTs § 106 (2d ed. 2014) (discussing the various ways that consent may be manifested by the plaintiff).

32 See Hellriegel v. Tholl, 417 P.2d 362, 367 (Wash. 1966); DobBS ET AL., supra note $31, \S 105$.

33 DoBBS ET AL., supra note 31, § 105.

34 See Restatement (SeCond) OF Torts § 892A cmt. b (1979); DOBBS ET AL., supra note $31, \S 109$ (stating that "mental limitations are not equivalent to incapacity"). The Second Restatement notes: "If the person consenting is a child or one of deficient mental capacity, the
} 
In addition, the defendant must have known, or had reason to know, of the plaintiff's incapacity. ${ }^{35}$ This rule raises an additional mental state question - the defendant's actual or constructive knowledge of the incapacity of the plaintiff. Whether the defendant should have known could become a complex question, requiring the defendant to be capable of understanding subtle nuances of behavior.

\section{B. The Law of Negligence}

In contrast to intentional torts, negligence doctrine contains more complex and fragmented rules regarding persons with mental disabilities. Although defendants ${ }^{36}$ have a duty to exercise reasonable care to avoid injury to the plaintiff, 37 the parameters of the duty in a particular case are set by the factual circumstances. Moreover, certain subjective characteristics of the defendant may be factors in determining duty and breach. Both mental and physical disabilities are considered when the actor is a child, along with the child's age and experience. With regard to adults a bifurcated rule applies, however, according to which

consent may still be effective if he is capable of appreciating the nature, extent and probable consequences of the conduct consented to . . .." RESTATEMENT (SECOND) OF TORTS $§ 892 \mathrm{~A} \mathrm{cmt.} \mathrm{b} \mathrm{(1979).} \mathrm{Where} \mathrm{a} \mathrm{law}$ has been enacted to protect children from the harmful effects of consent-such as statutory rape laws-consent will not be effective as a matter of law. See id.

35 See Reavis v. Slominski, 551 N.W.2d 528, 538 (Neb. 1996). In situations where the defendant had no reason to know of the existence of the incapacity, the reasonable appearance of consent, coupled with the defendant's reasonable belief that the plaintiff consented, suffices to render the consent legally effective. RESTATEMENT (SECOND) OF TORTS $§$ 892A(2) (1979).

36 This Article primarily uses the designations "defendant" or "tortfeasor" when referring to the duty rules in negligence. These terms are intended to encompass the plaintiff when the plaintiff's contributory or comparative negligence is at issue in the case. Generally, the duty of the plaintiff to avoid causing injury to herself parallels the duty of the defendant to avoid causing injury to a third person (the plaintiff). See Restatement (Third) of Torts: Liab. For Physical and Emotional HARM $§ 3 \mathrm{cmt}$. b (2010).

37 Id. $\S 7$ (noting that in exceptional cases a court may impose a noduty rule). 
physical disabilities, but not mental disabilities, may be considered in determining duty and breach. The same bifurcated rule applies to plaintiffs who are alleged to have been contributorily negligent in causing their own injuries. ${ }^{38}$

The bifurcated rule has had a long and dubious pedigree in negligence law. ${ }^{39}$ In Johnson v. Lambotte, ${ }^{40}$ the adult defendant, a hospital inpatient, had been treated without improvement for chronic paranoid schizophrenia. At the time of the accident, and on the date in question in the case, she was receiving frequent high doses of thorazine. ${ }^{41}$ Upon leaving the hospital without being properly discharged, she walked eight blocks, entered an empty car with the motor running, and began driving, whereupon she collided with the plaintiff's car. She continued on, and another accident occurred in which she was injured. ${ }^{42}$ In the plaintiff's

$38 \quad I d$. $§ 3 \mathrm{cmt}$. b ("The definition of negligence set forth in this Section applies whether the issue is the negligence of the defendant or the contributory negligence of the plaintiff."). The Third Restatement of Torts: Apportionment of Liability posits the adoption of comparative negligence principles for intentional torts, with apportionment of liability between parties found to be at fault, including the plaintiff. See REstATEMENT (THIRD) OF TORTS: APPORTIONMENT OF LIAB. $\S 1 \mathrm{cmt}$. c (2000). Comment c states: "Although some courts have held that a plaintiff's negligence may serve as a comparative defense to an intentional tort, most have not. This Restatement takes no position on that issue." Id. Although the Restatement explicitly acknowledges the complexity of the issues involved in allowing the plaintiff's negligence to reduce her recovery for an intentional tort, it does not attempt to fully analyze or solve those issues. Id. For the moment, there does not appear to be a trend toward allowing the comparative negligence of the plaintiff to reduce recovery in an intentional tort case. The Third Restatement Reporters state that most jurisdictions allowing comparative negligence principles for apportionment of fault in intentional tort cases do so only among defendants, not as between the plaintiff and the defendant. Id. reporters' note to cmt. c \& cases cited therein. Allowing evidence of the plaintiff's negligence to impact the plaintiff's recovery in an intentional tort action would likely invoke the rules of duty discussed in this Article and would raise the potential for a conflicting set of rules when the plaintiff is mentally disabled.

39 See Williams v. Hays, 38 N.E. 449, 450 (N.Y. 1894).

40363 P.2d 165, 165 (Colo. 1961).

41 Id.

$42 I d$. at 166. 
personal injury action, the defendant argued that she should not be held liable because she had no ability to distinguish between right and wrong at the time of the accident and because she had not acted negligently. At trial, the plaintiff recovered a judgment. ${ }^{43}$ Applying the general rule, the Colorado Supreme Court held that the plaintiff could be held liable for her torts regardless of her mental condition and that the standard of care to which she must be held under the law of negligence was the same as a person without her mental condition. ${ }^{44}$ Cases such as Johnson impose an objective standard-the reasonable person without mental disabilities-on adults with mental disabilities.

The Second Restatement articulated the reasons for the tenacity of this prevailing rule and cemented its underlying rationales. ${ }^{45}$ The Second Restatement relied on four familiar policies in sustaining the viability of the historical rule: (1) the difficulty of distinguishing "mental deficiency" from lesser "variations of temperament, intellect, and emotional balance;" (2) the concern that-and "ease with which"-parties could fabricate symptoms of mental illness for the purpose of escaping liability; (3) requiring persons with mental conditions to compensate the persons they injure if they "are to live in the world;" and (4) encouraging caretakers to prevent mentally challenged family members from doing harm to others. ${ }^{46}$

43 Id.

44 Id.

45 Section $283 \mathrm{~B}$ of the Second Restatement stated: "Unless the actor is a child, his insanity or other mental deficiency does not relieve the actor from liability for conduct which does not conform to the standard of a reasonable man under like circumstances." RESTATEMENT (SECOND) OF TORTS § 283B (1965).

46 The Second Restatement's language reflects outmoded attitudes toward mentally ill or otherwise mentally challenged persons. The rule contains such terms as "mental defectives." See id. cmt. b(3). And the tone of the language is sometimes insensitive and reflects negative stereotypes. For example, in stating the fourth policy noted in the text, the Restatement states: "The belief that their liability will mean that those who have charge of them or their estates will be stimulated to look after them, keep them in order, and see that they do not do harm." Id. cmt. b(4). 
This objective rule for adults with mental disabilities contrasts sharply with the subjective rule for persons with physical disabilities. The Third Restatement states: "The conduct of an actor with a physical disability is negligent only if the conduct does not conform to that of a reasonably careful person with the same disability." 47 This subjective standard allows the particular defendant's physical disability to be a factor in determining some important aspects of negligence-the nature of the duty owed, the amount of care required under the circumstances, and whether the duty was breached under the circumstances of the case. Comment a indicates that for a physical disability to be considered it must be "significant and objectively verifiable." 48 While old age is not in itself a physical disability and would not fit the basic rule, age-related physical disabilities would be treated as any other physical disability under the rule. 49

The Third Restatement continues to espouse the majority bifurcated rule, however, which imposes an objective standard on adults with mental disabilities. ${ }^{50}$

\footnotetext{
47 Restatement (ThiRd) OF ToRts: Liab. FoR Physical AND EMOTIONAL HARM $§ 11(\mathrm{a})(2010)$.

$48 \quad I d . \S 11$, cmt. a.

49 Id. cmt. c.

50 Id. $\S 11(\mathrm{c})$ ("An actor's mental or emotional disability is not
} considered in determining whether conduct is negligent, unless the actor is a child."). The rule for mentally disabled persons is also applied to involuntarily intoxicated persons. See id. $\S 12 \mathrm{cmt} \mathrm{c.} \mathrm{A} \mathrm{person} \mathrm{who} \mathrm{is}$ involuntarily intoxicated is one who has not been drugged against his or her will. DoBBS ET AL., supra note 31, § 133 n.1. This rule also applies to persons who have not previously engaged in the particular activity involved in the tort, and to persons with poor memories. In contrast, special skills or training are factors that should be considered in determining how the reasonable person with such skills or training would have acted under the circumstances. Persons with special skills or training are held to exercise the care that a reasonable person with those skills would exercise-in other words, specialized care which often would mean more care than a person without those skills would exercise. The Third Restatement states: "If an actor has skills or knowledge that exceed those possessed by most others, these skills or knowledge are circumstances to be taken into account in determining whether the actor has behaved as a reasonably careful person." Restatement (Third) of Torts: Liab. For Physical AND EMOTIONAL 
Although comment e recognizes the flaws in this traditional rule, the Restatement continues to embrace it because of perceived difficulties applying a rule that allows mental disabilities to be a factor. The comment states that "limited or moderate mental disorders" should not be taken into consideration because such conditions do not generally account for a person's actions and because of the difficulties of evaluating the impact of these conditions on the person's behavior under the relevant circumstances. ${ }^{51}$ The American Law Institute (ALI) does not dispute that the more severe mental conditions may have behavioral ramifications, but expresses the opinion that administrative difficulties-such as the "awkwardness experienced by the criminal-justice system in attempting to litigate the insanity defense"support retaining the bifurcated rule. ${ }^{52}$ The ALI also cites difficulties in determining whether there was a causal connection between the condition and the conduct of the person. Finally, the comment emphasizes the deterrent value of holding liable persons within the entire range of mental and emotional disabilities. Liability, at least theoretically, would raise questions about the person's ability "to engage in the normal range of society's activities." Recognizing that modern social policy favors deinstitutionalization of persons with mental disabilities, making available compensation for their injured victims becomes a preferred goal. ${ }^{53}$

HARM $§ 12$ (2010). Clearly the Restatement contemplates the exercise of more care —or at least more specialized care-by such persons, not less care. In contrast, the Third Restatement notes the refusal to allow below-average skills or knowledge to be considered when determining the duty owed. For one thing, "the acquisition of knowledge and skills is a process that is generally within a person's control." Id. cmt. b.

51 Restatement (ThiRd) OF TORTs: Liab. FOR PHYsical AND EMOTIONAL HARM $§ 11 \mathrm{cmt}$. e (2010).

$52 I d$.

53 The comment states:

[T]here is nothing especially harsh in at least holding such a person responsible for those harms that the person's clearly substandard conduct causes. The theory of deinstitutionalization implies that even persons with severe mental disorders can adequately comply with society's norms; while reality may fall short 
More importantly, the Third Restatement acknowledges the known organic basis for many mental conditions, yet chooses to disregard that fact in endorsing the bifurcated rule. Comment e to Section 11 states: "To be sure, modern society is increasingly inclined to treat physical disabilities and mental disabilities similarly, and this inclination is supported by the recognition that many mental disabilities have organic causes." 54 Nonetheless, the Restatement and the courts have reached the perverse conclusion that the legal duties of persons with mental disabilities under negligence law should be different from those of persons with physical disabilities.

Burch v. American Family Mutual Insurance Co.55 is a classic illustration of the bifurcated rule's contradictions. In Burch, the plaintiff was the father of the mentally challenged minor defendant. The plaintiff was injured when he left the defendant sitting in the front seat of his pickup truck with the engine off and the key in the ignition. When the plaintiff was behind the truck, the truck lurched backward, allegedly by a negligent act of the defendant, injuring the plaintiff. 56 In the court's words, the fifteenyear-old defendant was born with "cerebral palsy and mental retardation with autistic tendencies and function[ed] at the cognitive level of a preschooler." 57 The Wisconsin Supreme Court held that the traditional rule barring consideration of the defendant's mental condition applied in the case. ${ }^{58}$ The court observed that the

\footnotetext{
of theory, deinstitutionalization becomes more socially acceptable if innocent victims are at least assured of opportunity for compensation when they suffer injury.

Id.

54 Id.

55543 N.W.2d 277 (Wis. 1996).

56 Id. at 278-79.

57 Id. at 278.

$58 I d$. at 280 . The court distinguished a simultaneously issued decision which held that under certain circumstances an institutionalized mentally disabled person will not be held liable in tort to a paid caretaker. See Gould v. Am. Family Mut. Ins. Co., 543 N.W.3d 277, 283 (Wis. 1996) (holding that "an individual institutionalized, as here, with a mental disability, and who does not have the capacity to
} 
defendant's mental conditions were "physical/organic in nature and have been present since her birth." 59 Nevertheless, the court held that the defendant's mental condition could not be considered in determining whether she breached a duty of care. ${ }^{60}$ The court noted, however, that the defendant's mental condition, and her father's knowledge of the condition, could be taken into consideration in determining whether the plaintiff was contributorily negligent in leaving his daughter in the car with the key in the ignition. ${ }^{61}$ Thus, the court's application of the traditional rule was doubly perverse in the Burch case. First, the court acknowledged the "physical/organic" basis of the defendant's mental condition, yet steadfastly refused to allow the mental disability to be treated like a physical disability when determining duty and breach of duty. Second, the court turned around and allowed the mental condition of the defendant to be considered for purposes of determining whether the plaintiff was contributorily negligent.

Notwithstanding such inconsistencies, courts often state that they adhere to the bifurcated rule because allowing mental disabilities to be considered would be "one-sided" and would invariably result in a lesser standard of care as a matter of law-and therefore fewer instances of liabilityfor persons with mental conditions than those with physical conditions. ${ }^{62}$ Physical disabilities may require the actor to exercise more care or less care depending upon the disability and the circumstances. In Roberts v. State, a blind defendant collided with the plaintiff in the lobby of a post office. 63 The defendant, who operated a concession

control or appreciate his or her conduct cannot be liable for injuries caused to caretakers who are employed for financial compensation"); infra notes 94-102 and accompanying text.

59 Burch, 543 N.W.3d at 281.

60 This rule was especially harsh considering that the defendant was a minor.

61 Burch, 543 N.W.3d at 280 n.4.

62 See Restatement (Third) of Torts: Liab. FOR Physical And EMOTIONAL HARM § $11 \mathrm{cmt}$. e (2010).

63 Roberts v. State, 396 So.2d 566, 566 (La. Ct. App.), aff d, 404 So.2d 1221 (La. 1981). 
stand in the lobby, was walking down the hall toward the restroom without the use of a cane and without holding his hand in front of him. The plaintiff claimed that the defendant was negligent in failing to use a cane, even though he had the cane available at his concession stand. ${ }^{64}$ The court upheld the trial court's dismissal of the action. ${ }^{65}$ Noting that "it is not uncommon for blind people to rely on other techniques when moving around in a familiar setting," 66 the court did not require a blind defendant to use a cane as a matter of law. The record showed that the defendant had undertaken mobility training and had testified that on this particular occasion he relied on his "facial sense" without a cane, which he frequently used in moving around familiar surroundings. The reasonableness of this technique was supported by the testimony of witnesses from the Division of Blind Services. ${ }^{67}$ The court concluded that he "was acting as a reasonably prudent blind person would under these particular circumstances."68 Roberts suggests, however, that in other circumstances reasonableness would require a blind defendant to use a cane. The reasonableness of the physically disabled person is generally a question of fact for the jury, and the outcome will depend on the detailed interaction of the nature and extent of the individual party's physical condition compared to the circumstances of the case. ${ }^{69}$ Thus, the presence of a

64 Id. at 567.

65 Id. at 569.

66 Id. at 568.

67 Id. at 567-68.

68 Id. at 567.

69 See Shepherd v. Gardner Wholesale, Inc., 256 So.2d 877 (Ala. 1972). The plaintiff in Shepherd tripped and fell on a public sidewalk abutting the defendant's business. Id. at 878 . The question was the contributory negligence of the plaintiff, a person with a vision impairment due to cataracts. The court stated:

While the law requires a pedestrian to make reasonable use of his sense of sight, a person with impaired vision is not required to see what a person with normal vision could see. . . A person laboring under a physical disability such as defective vision is not required to exercise a higher degree of care to avoid injury than is required of a person under no disability. 
physical disability may in some circumstances require more care than would be required in the absence of the disability, depending upon what the particular physical limitation allows.

The Third Restatement reflects cases such as Roberts: "Physical disability can both advantage and disadvantage actors at trial . . . . It can advantage the actor by establishing that the actor neither knew nor should have known of dangers that would have been known by others." 70 On the other hand, "persons with particular disabilities can appreciate that some conduct on their part will foreseeably entail a greater risk than the same conduct engaged in by able-bodied persons." 71 When such risks are foreseeable, a person "can be found negligent for not adopting special precautions that can reasonably reduce the special dangers that the actor's conduct involves."72 Persons with physical

Id. at 882 .

The Third Restatement expands upon this point:

With physical disabilities . . . tort law tailors the negligence standard to acknowledge the individual situation of the actor. To this extent, tort law employs what can be called a subjective rather than a fully objective standard of care. Of course, the weight to be attached to the subjective fact of disability depends on the contents of the particular claim of negligence.

Restatement (Third) of Torts: Liab. FOR Physical AND EMotional HARM $\S 11$ cmt.b (2010). This is substantively different from the treatment of mentally challenged persons.

70 Restatement (ThiRd) OF TORTs: Liab. For Physical AND EMOTIONAL HARM $\S 11 \mathrm{cmt} . b$ (2010).

71 Id.

72 Id. The example presented in the Third Restatement is that of a blind person who is incapable of seeing certain hazards. He or she would not be required to avoid the unseen hazard in the same manner as a fully sighted person. In contrast, a blind person may be required to exercise a greater amount of care under some circumstances, such as traversing unfamiliar territory. See id; see also Hosmer v. Distler, 541 N.Y.S.2d 650 (N.Y. App. Div. 1989). The Hosmer case involved an injured pedestrian hit by a motorist who at the time of the accident was wearing bifocals, wore a left leg prosthesis, and was taking medication for various ailments, including diabetes. The court stated that because he "chose to drive with full knowledge of his disabilities he is to be held to the standard of a reasonable licensed driver [and that he] had the 
disabilities are expected only to adopt appropriate safety precautions given the increased risks associated with their physical conditions. ${ }^{73}$ Persons with mental disabilities, by contrast, must adopt any and all safety precautions expected of a person without their mental conditions.

A special rule applies to children. When the mentally disabled person is a child, the applicable rule is a fully subjective one whereby the mental disability will be a factor in the duty analysis. ${ }^{74}$ The Second and Third Restatements of Torts are consistent on the duty of children: "A child's conduct is negligent if it does not conform to that of a reasonably careful person of the same age, intelligence, and experience."75 Very young children are generally deemed to be incapable of negligence. ${ }^{76}$ Logical reasons exist for the

additional responsibility of exercising caution to compensate for any increased hazard occasioned by his known disabilities." Id. at 652 .

73 Restatement (ThiRd) OF TORTs: Liab. FOR Physical AND EMOTIONAL HARM $\S 11 \mathrm{cmt} . b$ (2010) ("While it is sometimes said that an actor with a disability must adopt precautions that "compensate" for that disability, obviously complete compensation is often impracticable; what is required is the adoption of reasonable precautions such that their safety advantages outbalance their disadvantages and inconveniences.").

74 See id. § 11(c). Section 11(c) provides: "An actor's mental or emotional disability is not considered in determining whether conduct is negligent, unless the actor is a child."

75 Id. § 10(a); see Sherry v. Asing, 531 P.2d 648, 661 (Haw. 1975) (stating that "[t]he rule in this and a clear majority of jurisdictions is that a minor is required to exercise care appropriate to his age, experience and mental capacity"); RESTATEMENT (SECOND) OF TORTS $\S$ 283A (1965).

76 Restatement (THIRD) OF TORTS: LiAB. FOR PhySiCAL AND EMOTIONAL HARM $§ 10$ (b) (2010) ("A child less than five years of age is incapable of negligence."); see, e.g., Taylor v. Armiger, 358 A.2d 883, 889 (Md. 1976); Mathis v. Massachusetts Elec. Co., 565 N.E.2d 1180, 1184 (Mass. 1991). Children approaching the age of majority may present a special challenge. In Dorais v. Paquin, a case involving the question of the contributory negligence of a 17-year-old child, the New Hampshire Supreme Court applied the subjective standard for children on the ground that "[c]hildren generally do not have the same capacity to perceive, appreciate and avoid dangerous situations which is possessed by the ordinary, prudent adult." Dorais v. Paquin, 304 A.2d 369, 371 (N.H. 1973). Because of the near-majority age of the child in the case, however, the court held that the plaintiff child's duty to avoid injury 
subjective rule, including that "children are less able than adults to understand risks, to appreciate alternative courses of conduct with respect to risks, and to make appropriate choices from among those alternatives." 77 This rule, along with its underlying policies, applies equally to children of all mental capabilities. 78 Once the circumstances are proved, the child must demonstrate conformity with the judgment of a reasonable person with the particular mental condition. ${ }^{79}$ A universally recognized and common exception involves a child engaged in an adult activity, in which case the child will be held to the standard of an adult engaged in that activity. 80

An example of the application of the subjective rule to a child is Lafayette Parish School Board v. Cormier ex rel. Cormier. ${ }^{81}$ The school board brought suit against the mother of an eleven-year-old special education student, claiming that the student had caused a teaching assistant to suffer emotional distress by pointing a toy gun at her and yelling "bang." 82 The court agreed with the trial court that the student had not breached the applicable duty of care, which was that of "a reasonably prudent 11-year-old boy

was the same as an adult. The court noted that "[t]he closer a child comes to majority, and the more common and obvious the risk ... the more likely it is that the youth will be held to the adult standard of care." Id. at 372 (internal citation omitted). But cf. Alabama v. Miller, 132 U.S. 2455, 2464-65 (2012) (stating that fundamental differences exists between juvenile and adult minds so as to preclude mandatory life imprisonment without parole for persons under the age of eighteen); Roper v. Simmons, 543 U.S. 551, 578 (2005) (referencing neuroscientific studies in holding that the death penalty for persons under the age of eighteen at the time of the capital crime is unconstitutional).

77 Restatement (ThiRd) OF TORTs: Liab. FOR Physical AND EMOTIONAL HARM $\S 10 \mathrm{cmt}$. b (2010).

78 Id. $\S 10$ (a) \& cmt c (stating that "any evidence of mental or emotional deficit can be considered").

79 Restatement (SECOND) OF ToRTs § 283A cmt. b (1965).

80 See Dellwo v. Pearson, 107 N.W.2d 859, 863 (Minn. 1961); RESTATEMENT (SECOND) OF TORTS § 283A cmt.c (1965).

81 Lafayette Parish School Bd. v. Cormier ex rel. Cormier, 901 So. 2d 1197 (La. Ct. App. 2005).

82 Id. at 1198-99. The record indicated that the student's challenges were "emotional disturbance" and "impulsive and aggressive behavior." Id. at 1199 . 
who has the same exceptionalities" as the student whose conduct was at issue in the case. ${ }^{83}$ In Young v. Grant, the subjective standard cut the other way, however. In Young, the plaintiffs' minor daughter was injured riding her bicycle when she was struck by a car driven by the defendant. 84 The defendant alleged the contributory negligence of the minor plaintiff, who was ten years old and mentally challenged. The court stated that although questions of fact may have existed, "all of the evidence in the record (and particularly the testimony of her mother ...) supports the conclusion that she was a competent cyclist and that she appreciated the dangers of city traffic." 85 Accordingly, it was not error to conclude, as had the trial court, that she had not exercised the judgment of a reasonable child of her age, intelligence, and experience and was therefore contributorily negligent in the accident. ${ }^{86}$

The Restatement explains that the special rule for children is justified by public concern for their safety and welfare. Moreover, the Restatement notes that understanding the behavior of children of all ages, experience, and mental ability is within the apprehension of the general public. 87 But could not the same arguments be made to justify applying the subjective rule to adults with mental disabilities? The variations in abilities and temperaments of adults with mental disabilities are surely no greater than among children. And predicting the behavior of children with mental disabilities is outside the basic understanding of most members of the public.

\section{Judicial Exceptions to the Bifurcated Rule}

83 Id., at 1203 (quoting the trial court).

84 Young v. Grant, 290 So. 2d 706, 707 (La. Ct. App. 1974).

85 Id. at 710-11. The court stated further that the record indicated that "this child, ten years of age, and having about six years' experience in handling a bicycle was of sufficient capacity to realize the obvious danger of turning her bicycle into the path of an oncoming automobile only ten feet away from her despite her mentally retarded condition." Id. at 710 .

86 Id. at 711.

87 Restatement (SECOND) OF ToRTs $§ 283 \mathrm{~A} \mathrm{cmt.} \mathrm{b} \mathrm{(1965).}$ 
Some courts have recognized that the bifurcated rule for adults achieves anomalous or unfair results under certain circumstances and have developed exceptions on public policy grounds. The Supreme Court of Wisconsin has been especially active in this respect. In Breunig v. American Family Insurance Co.,88 the Wisconsin Supreme Court expanded the "sudden incapacitation" defense in negligence law to encompass at least some mental conditions. In so doing, the court departed from the majority rule which the Third Restatement states as follows: "The conduct of an actor during a period of sudden incapacitation or loss of consciousness resulting from physical illness is negligent only if the sudden incapacitation or loss of consciousness was reasonably foreseeable to the actor." 89 The defense as so stated applies only when the sudden incapacitation is due to "physical illness," not mental illness. And liability is foreclosed only if the party could not have reasonably foreseen the onset of the incapacitation.

The Wisconsin Supreme Court, however, broadened the rule to encompass sudden mental incapacitation. Breunig involved a motor vehicle accident in which the alleged tortfeasor's insurer argued that its insured could not be found negligent because "just prior to the collision she suddenly and without warning was seized with a mental aberration or delusion which rendered her unable to operate the automobile with her conscious mind." 90 Extending the traditional rule, the court held that the jury should have been allowed to consider the evidence of the insured's mental illness. ${ }^{91}$ The court stated this broader rule as follows:

\footnotetext{
88173 N.W.2d 619 (Wis. 1970).

89 Restatement (THIRD) OF TORTS: LiAB. FOR PHYSICAL AND EMOTIONAL HARM $§ 11(\mathrm{~b})(2010)$.

90 Breunig, 173 N.W.2d at 621-22.

91 On appeal from a jury verdict for the plaintiff, the Wisconsin Supreme Court began its opinion by stating that at the time of the accident, the insured was in the throes of "an insane delusion" that interfered with her ability to drive the automobile as a reasonably prudent person would. Id. at 622 . The conclusion was supported by the testimony of the insured's treating psychiatrist, who stated that at the time of the accident she suffered from acute paranoid schizophrenia and
} 
The effect of the mental illness or mental hallucinations or disorder must be such as to affect the person's ability to understand and appreciate the duty which rests upon him to drive his car with ordinary care, or . . . it must affect his ability to control his car in an ordinarily prudent manner. ${ }^{92}$

The court saw no valid legal distinction between physical and mental incapacitation that would merit a different result, provided that the incapacitation was unforeseeable. ${ }^{93}$ This rule implicitly acknowledges that, at least in some tort contexts, a distinction between the mentally disabled person and the physically disabled person is unwarranted. It also suggests that a subjective standard for adult defendants is workable, regardless of whether the disability is physical or mental.

Gould v. American Family Mutual Insurance Co. presented a different set of circumstances that warranted treating mental and physical disabilities the same under the law of negligence. Gould involved a plaintiff who was the head nurse of a dementia unit in a health care facility and who was injured by the defendant's insured, an Alzheimer's patient in the facility. ${ }^{94}$ The trial court refused to give an instruction that would have required the jury to consider the insured's mental state, and the jury found the insured one hundred percent negligent. ${ }^{95}$ The Wisconsin

had no advance warning that she would be overtaken by a delusion to the extent that she could not operate her automobile. Id. at 622-23. The opinion contained nothing that would suggest that the psychiatrist's testimony included any overt discussion of the physical basis of the insured's mental illness.

92 Id. at 623.

93 One reason the court may have been willing to go the distance in applying the sudden incapacitation defense to a sudden mental disability was that the circumstances logically ruled out the possibility that the insured would have feigned her condition to avoid liability.

94 Gould v. Am. Family Mut. Ins. Co., 543 N.W.2d 282, 283 (Wis. 1996).

95 Id. at 284. 
Supreme Court held, however, that where the alleged tortfeasor is institutionalized for a mental disability, and the plaintiff is his or her professional caretaker, ${ }^{96}$ the defendant's mental disability must be considered. ${ }^{97}$

The Gould court reasoned that three of the most often invoked policies to support the bifurcated rule failed in the caretaker context. ${ }^{98}$ First, the court noted that this was not a case between two "innocent" parties requiring that the loss shift to the defendant. Rather, the plaintiff could not be considered "innocent" because she was employed as a caretaker, had professional training and held a supervisory position, and was familiar with the insured's propensity for violent outbursts related to his mental condition. 99 Second, the threat of liability would have no further deterrent value on those who may be interested in his estate, as his family had already made the ultimate decision to place him in a secure dementia facility. ${ }^{100}$ Third, the notion that a person would feign the symptoms of Alzheimer's disease and undergo institutionalization simply to avoid the possibility of tort liability in the future was "incredible."101 Courts in several other jurisdictions have created a similar exception

96 Alternatively, the doctrine of primary assumption of the risk has been successfully invoked in some cases addressing similar factual circumstances. For example, in Gregory v. Cott, 152 Cal. Rptr. 3d 304 (Cal. Ct. App. 2013), aff d, 331 P.3d 179 (Cal. 2014), a claim brought by an in-home caregiver against an Alzheimer's patient was dismissed on summary judgment based upon the defense of assumption of the risk. The court stated the general rule that recovery will be denied to a plaintiff when 'the nature of the activity involved and the parties' relationship to the activity [establishes that] the defendant owed the plaintiff no duty of care." Id. at 307 (quoting Neighbarger v. Irwin Indus., Inc., 882 P.2d 347, 351 (Cal. 1994)). The court then concluded that a person hired to care for an Alzheimer's patient, whether in the patient's home or in a care facility, has assumed the risk of injury from the dangerous propensities of the patient. Id. at 310.

97 Gould, 543 N.W.2d 282 at 287.

98 The court stated: "[W]e conclude that this rule does not apply in this case because the circumstances totally negate the rationale behind the rule and would place an unreasonable burden on the negligent institutionalized mentally disabled." Id.

99 Id. at $286-87$.

$100 I d$. at 287.

101 Id. 
to the traditional bifurcated duty rule for the circumstances presented in the Gould case. ${ }^{102}$

Such exceptions represent significant, if small, steps toward relieving persons with mental disabilities from the strictures of a bifurcated rule that no longer fits most situations. These exceptions favor a case-by-case analysis of whether the circumstances of an individual case serve the policies underlying the traditional rule. Thus, the nature and extent of the alleged tortfeasor's disability would be a factor or circumstance-along with all the other relevant circumstances-in determining the nature of the duty owed, if any, to the plaintiff. If rejection of the objective standard for persons with mental disabilities is appropriate in some situations, it is reasonable to ask whether the bifurcated rule has any continued viability. Does an objective standard for persons with mental disabilities continue to make sense in an era in which neuroscientific technologies are capable of providing more information than ever about the link between the brain and behavior? Would a subjective standard-and a unified one for all torts-better serve the interests of mentally disabled parties and society in general? The remainder of this Article explores the role that neuroscience may play in answering these questions.

\section{MENTAL DISABILITY IN TORT DOCTRINE: IS THERE A ROLE FOR NEUROSCIENCE?}

This Article argues that neuroscience provides crucial support for reforming negligence doctrine so as to create a subjective standard for mentally disabled parties in tort actions. Neuroscience evidence, when appropriately admitted, may reduce guessing in the courtroom about the relationship between the person's mental condition and his

102 See Colman v. Notre Dame Convalescent Home, Inc., 968 F. Supp. 809, 814 (D. Conn. 1997); Mujica v. Turner, 582 So. 2d 24, 25 (Fla. Dist. Ct. App. 1991); Anicet v. Gant, 580 So. 2d 273, 275 (Fla. Dist. Ct. App. 1991) (stating that the same rule and exception apply to intentional torts and negligence); Creasy v. Rusk, 730 N.E.2d 659, 667 (Ind. 2000); Berberian v. Lynn, 845 A.2d 122, 123 (N.J. 2004). 
or her behavior in the circumstances of the case. Neuroscience may also play a role in correcting inaccurate stereotypes of the mentally disabled. Most importantly, applying a subjective standard that allows neuroscientific evidence to demonstrate mental states would force courts to take a hard look at the policies underlying the bifurcated rule. Courts likely will find that information obtained from neuroimaging could eschew an outmoded doctrine based upon obsolete or ineffectual policies. But is neuroscience ready for legal prime time? This is a vigorously debated question. Many experts tout the value of neuroimaging studies while cautioning against an overly enthusiastic espousal of studies that may promise more than they can deliver. ${ }^{103}$

\section{A. A Very Brief Look at the Advantages and Weaknesses of Functional Neuroimaging}

Mental disability in tort cases may be explained by both traditional psychiatric diagnosis or by psychiatric diagnosis combined with information obtained from structural and functional neuroimaging. Structural neuroimaging, such as the well-known techniques of magnetic resonance imaging (MRI) and computed tomography (CT) scans, and neurophysiological techniques such as the electroencephalogram (EEG) have been mainstays in identifying brain abnormalities. ${ }^{104}$ More recently, functional neuroimaging techniques have been able to provide psychiatrists with additional information about

103 See Geoffrey K. Aguirre, Functional Neuroimaging: Technical, Logical, and Social Perspectives, in Special Report: Interpreting Neuroimages: An Introduction to the Technology and Its Limits, HASTINGS CtR. RPT. S8, S8 (Mar.-Apr. 2014). Professor Aguirre expressed concern for the use of neuroimaging outside its home discipline: "During its rapid growth, however, neuroimaging has made multiple lateral moves to new areas of intellectual investigation. A feature of this 'imaging colonization' is that the method has moved more quickly than the hard-won cautionary experience would recommend." $I d$. The law is one such new area requiring caution.

104 See generally NANCY C. ANDREASEN \& Donald W. Black, INTRODUCTORY TEXTBOOK OF PSYCHIATRY 101-15 (3d ed. 2001). 
brain function and dysfunction in persons with mental illnesses. ${ }^{105} \quad$ Functional neuroimaging incorporates technologies such as positron emission tomography (PET) scans, ${ }^{106}$ single photon emission computed tomography (SPECT) scans, ${ }^{107}$ and functional magnetic resonance imaging (fMRI)108 to observe brain function under certain controlled stimuli. ${ }^{109}$

105 Id. at 116 ("Through the extensive application of these functional imaging techniques ... we have learned a great deal about dysfunctions in neural circuitry that occur in mental illnesses.").

106 The PET scan involves the use of small amounts of radioactive chemicals that are injected into the subject which allow the technician to observe brain function by detecting the collection of radioactivity in various parts of the brain. The technician then analyzes this activity over time in a series of static images. Owen D. Jones et al., Brain Imaging for Legal Thinkers: A Guide for the Perplexed, 2009 STAN. TECH. L. REV. 5, ๆ 14 (2009).

107 The SPECT scan combines the technology of the cranial computed tomography $(\mathrm{CT})$ scan and the radioactive feature of the PET scan. CT scans use a combination of X-rays and dyes to detect physiological anomalies in the brain. See Henry T. Greely \& Anthony D. Wagner, Reference Guide on Neuroscience, in REFERENCE MANUAL ON SCIENTIFIC Evidence 747, 762-63 (Fed. Judicial Ctr. \& Nat'l Research Council of the Nat'l Acads eds., 3d ed. 2011). The SPECT process allows visualization of the flow of blood through the brain's blood vessels to observe brain function. See id. at 765 . Like the CT scan, a computer creates cross-sectional images of the brain, which may then be assembled into three-dimensional images.

108 fMRI is a variation of the widely used magnetic resonance (MRI) technology, which uses a strong magnet and radio waves to obtain detailed structural images of the brain. See What is fMRI?: Imaging Brain Activity, U.C. SAN DIEGO SCH. OF MED., http://fmri.ucsd.edu/Research/whatisfmri.html (last visited May 18, 2015). fMRI technology examines brain function in real time. The technician determines blood oxygen levels in part of the brain by detecting the activity of iron atoms in the blood. Certain distortions in the magnetic field may indicate changes in the brain associated with the particular task in which the subject is engaged. See Jones et al., supra note 106,918 . The underlying physiological principle is that whenever a particular part of the brain becomes active, the small blood vessels in that region dilate, causing more oxygenated blood to rush in. See Michael D. Fox \& Marcus E. Raichle, Spontaneous Fluctuations in Brain Activity Observed with Functional Magnetic Resonance Imaging, 8 NATURE ReVs. NeURosci. 700, 701 (2007) (stating that the term "active" refers to the detected oxygen level in a particular region of the 
What applicability may these techniques have to tort actions? Their potential is substantial. Diagnosis of a mental illness or other mental condition has traditionally been made by a psychiatrist who interprets the symptoms presented by the patient in conjunction with any clinical medical tests and determines whether they fall within the accepted professional parameters of a known condition. ${ }^{110}$ Although diagnoses serve a valuable purpose in the lawparticularly in medical malpractice litigation ${ }^{111}$ and in assessment of injury-diagnosis generally is not a prerequisite to a finding of tortious conduct. ${ }^{112}$ Some experts have suggested that functional neuroimaging may provide better information on behavior than reliance solely on psychiatric diagnosis. ${ }^{113}$ Both the psychiatric analysis of mental conditions and the physiological observation of functional brain systems may be applicable to a particular tortfeasor's conduct. Tort law-and much of law

brain in response to various stimuli). The analytical process used to detect this function is known as blood oxygen level dependent (BOLD) contrast. Daniel D. Langleben et al., True Lies: Delusions and LieDetection Technology, 34 J. Psychiatry \& L. 351, 359 (2006).

109 See ANDREASEN \& BLACK, supra note 104, at 115-21.

$110 I d$. at $22-23$.

111 Id. at 29.

112 See Paul S. Applebaum, Reference Guide on Mental Health Evidence, in ReFERENCE MANUAL ON SCIENTIFIC EvidenCe 813, 819 (Fed. Judicial Ctr. \& Nat'l Research Council of the Nat'l Acads. eds., 3d ed. 2011). Speaking generally about both civil and criminal law, Dr. Applebaum stated: "A diagnosis of mental disorder per se will almost never settle the legal question in a case in which mental health evidence is presented. However, a diagnosis may play a role in determining whether a claim or proceeding can go forward." Id. Yet, there are studies that have demonstrated a connection between organic brain damage or other brain condition and sociopathic behavior. See Dean Mobbs et al., Law, Responsibility, and the Brain, 5 PLOS BIOL. 0693 (2007), a vailable

http://journals.plos.org/plosbiology/article?id=10.1371/journal.pbio.0050 103.

113 See Lisa T. Eyler et al., Brain Response Correlates of Decisional Capacity in Schizophrenia: A Preliminary fMRI Study, 19 J. NEURopsychiatry \& Clinical NEURosci. 137, 138 (2007) (stating that "functional imaging may be a better tool for examining sources of variability in decisional capacity than neuropsychological measures alone"). 
generally-focuses on the ability of persons to function in a variety of social situations, both in terms of their capacity to make decisions and their ability to behave in socially and legally acceptable ways. ${ }^{114}$ Thus, theoretically at least, tort law could benefit from information obtained through the techniques of neuroimaging.

Neuroscience evidence has appeared steadily in criminal law cases in recent decades at all phases of criminal adjudication-pre-trial, guilt, sentencing, and postconviction. ${ }^{115}$ In State V. Marshall, for example, the defendant moved to withdraw his guilty plea to aggravated first degree murder on the ground of incompetency, arguing that the trial court had erroneously declined to convene a competency hearing. ${ }^{116}$ The court held that the record showed sufficient evidence to call into question the competency of the defendant when he sought to withdraw the plea because there was proof of "long-standing brain dysfunction, with significant atrophy in the temporal and frontal lobes." 117 The neuroscientific evidence included an MRI, a SPECT scan, and an EEG, all of which revealed abnormalities that experts opined were associated with impaired cognitive abilities. ${ }^{118}$ The court vacated the plea and remanded the case. ${ }^{119}$ In matters related to sentencing, the U.S. Supreme Court has weighed in on the value it attaches to neuroscience studies, at least with regard to brain development in juveniles. In Roper $v$. Simmons, the Supreme Court ruled that the Eighth and Fourteenth Amendments to the U.S. Constitution prohibit the death penalty for a person under the age of eighteen at the time of

\footnotetext{
114 See Applebaum, supra note 112, at 820.

115 See Grafton, supra note 6, at 55.

116 State v. Marshall, 27 P.3d 192, 198 (Wash. 2001).

117 Id. at 199.

118 Id. at 197.
}

119 Id. at 200. But see United States v. Hammer, 404 F. Supp. $2 d$ 676, 723 (M.D. Pa. 2005). In Hammer, although the court allowed neuroscientific data obtained from MRI and PET scans to be considered on the issue of the defendant's competence, the court ruled that the plaintiff's expert's opinion that the defendant was incompetent was not credible. Id. at 792-93. 
the capital crime for which he or she was convicted. ${ }^{120}$ In its opinion, the Court favorably referenced the amicus brief of the American Medical Association, the American Psychiatric Association, and other professional organizations, which discussed neuroscience studies, including those conducted using fMRI, on adolescent brain development. The amicus brief stated: "To a degree never before understood, scientists can now demonstrate that adolescents are immature not only to the observer's naked eye, but in the very fibers of their brains." ${ }^{21}$ The Court adopted this view of the juvenile brain and concluded that it rendered the death penalty unconstitutional for juveniles. ${ }^{122}$

By contrast, neuroscientific evidence in tort cases is scarce, except to prove damages. ${ }^{123}$ One reason for this may be practical. Tort law does not involve incarceration or capital punishment, and thus there is less urgency to obtain and introduce evidence from new technologies which may be

120 Roper v. Simmons, 543 U.S. 551, 578 (2005).

121 Brief for the American Medical Association et al. as Amici Curiae Supporting Respondent, Roper v. Simmons, 543 U.S. 551 (2005) (No. 03633), at 10.

122 Roper, 543 U.S. at 568. More recently, in Miller v. Alabama, 132 S. Ct. 2455 (2012), the Court once again gave its attention to the neuroscience of the juvenile brain. The Court held that mandatory life imprisonment without parole for persons under the age of eighteen violated the Eighth Amendment's prohibition of cruel and unusual punishment, noting that "brain science continue[s] to show fundamental differences between juvenile and adult minds." I Id. at 2464 (quoting Graham v. Florida, 560 U.S. 48, 68 (2010)). Referencing the line of cases about punishment of juveniles, the Court declared: "Our decisions rested not only on common sense-on what 'any parent knows'-but on science and social science as well." Id.

123 Clearly brain scans of various sorts prove useful in tort cases, mostly to identify structural problems, such as fractures, bleeding, or other anomalies. What is more difficult is the task of determining the extent to which a plaintiff may be experiencing pain. See generally Adam J. Kolber, The Experiential Future of the Law, 60 EMORY L.J. 585, 608-13 (2011) (discussing the potential role of neuroimaging in compensation for pain in tort); Adam J. Kolber, Pain Detection and the Privacy of Subjective Experience, 33 AM. J.L. \& MED. 433, 443-49 (2007) (discussing using neuroimaging techniques to measure pain and suffering). 
expensive. ${ }^{124}$ Another reason may be that neuroscienceand any other area of scientific endeavor that seeks to provide a complete explanation of human behavior-may be viewed as antithetical to the social norms inherent in tort law. Professor Stephen J. Morse has stated that criminal law is based on "folk psychology," which views humans as rational beings and not "mechanical forces of nature." 125 This same general concept lies at the foundation of tort law, and courts resist any model of tort law that views persons as acting without this element of reason and choice. ${ }^{126}$ But neuroscience need not be so viewed. ${ }^{127}$ Rather, neuroscience may be a means to advance the goals of tort law. This Article urges courts to expand their notion of the traditional model of tort law to allow neuroscience to facilitate the accurate resolution of disputes and reform outmoded doctrines.

124 Cf. Stephen J. Morse, Neuroimaging Evidence in Law: A Plea for Modesty and Relevance, in NEUROIMAGING IN ForEnsic Psychiatry: From the Clinic to the Courtroom 341, 342 (Joseph R. Simpson ed., 2012) (stating that the use of neuroimaging in criminal cases appears to be scarce (though precise estimates of its use are difficult because of the propensity for criminal cases to end in plea bargains), in part because of the expense of the technology).

125 See Stephen J. Morse, Determinism and the Death of Folk Psychology: Two Challenges to Responsibility from Neuroscience, 9 MinN. J.L. SCI. \& TECH. 1, 4 (2008). Morse focuses his discussion on responsibility in criminal law, but many of his points ring true for tort law as well.

126 Even in the areas of tort law governed by strict liability, defendants have voluntarily chosen to engage in the activity, such as blasting (strict liability for an abnormally dangerous activity), knowing the risk of tort liability. See, e.g., Sterling v. Velsicol Chem. Co., 647 F. Supp. 303, 315-16 (W.D. Tenn. 1986) (strict liability for disposing of toxic waste), aff'd in part, rev'd in part and remanded 855 F.2d 1188 (6th Cir. 1988).

127 In speaking of the relevance that neuroscience may have to the law (and to criminal law in particular) Professor Morse has stated: "The question is whether the new neuroscience is legally relevant because it makes a proposition about responsibility or competence more or less likely to be true. Any legal criterion must be established independently, and biological evidence must be translated into the criminal law's folkpsychological criteria." Stephen J. Morse, Avoiding Irrational Neurolaw Exuberance: A Plea for Neuromodesty, 62 Mercer L. REV. 837, 841 (2011). 
But courts must also exercise caution. Commentators are not in agreement about either the meaning of the information obtained from neuroimaging or the utility of neuroscientific information in determining legal issues. ${ }^{128}$ Indeed, disagreement exists within the neuroscience community on the interpretation of neuroimaging studies. 129 One source of skepticism has been the fact that many brain functions are recruited to process the information relevant to the particular task a study subject is engaged in; accordingly, identification of the precise brain processes involved may be speculative. This is particularly relevant to the kinds of normative judgments that the law makes. ${ }^{130}$ Moreover, individual results may vary from the averages employed in interpreting scan data. 131 Concerns abound over the problems of reproducing results, ${ }^{132}$ and commentators have warned that the technology of brain imaging has all the hallmarks of an emerging science that has not yet achieved full reliability. ${ }^{133}$ Translating clinical

128 See Teneille Brown \& Emily Murphy, Through a Scanner Darkly: Functional Neuroimaging as Evidence of a Criminal Defendant's Past Mental States, 62 StAN. L. Rev. 1119, 1162 (2010); Greely \& Wagner, supra note 107, at 782.

129 See, e.g., Brown \& Murphy, supra note 128, at 1140-41 (stating that in fMRI studies there lacks scientific consensus on how to interpret the relationship between the observable BOLD response and conclusions about the brain activity or mental states of subjects).

130 See Oliver R. Goodenough \& Kristin Prehn, A Neuroscientific Approach to Normative Judgment in Law and Justice, 359 PHIL. Trans. R. SOC'Y LOND. SERIES B, BIOL. SCI. 1709, 1717 (2005).

131 Jones et al., supra note 106, ๆ 33. Professors Greely and Iles have pointed out: "It is . . possible that two independent subjects will show different patterns of [brain] activation while their behavioral performances are comparable. Although subjects perform the same behavioral task, they might employ different strategies, thereby recruiting different neural networks, resulting in different patterns of activation." Henry T. Greely \& Judy Illes, Neuroscience-Based Lie Detection: The Urgent Need for Regulation, 33 AM. J.L. \& MED. 377, 382 (2007).

132 See William R. Uttal, Neuroscience in the Courtroom: What Every Lawyer Should Know About The Mind and the Brain 55-61 (2009).

133 Morse, supra note 124, at 344 (stating that the "neuroscience of cognition and interpersonal behavior is largely in its infancy"); see Eggen \& Laury, supra note 9, at 302-03 (noting that courts are likely to 
studies conducted under artificial circumstances may not yet provide optimal—or even minimal-information on the real-world situations that tort cases address.

In addition to the problem of reliably applying neuroscientific data to real-world human interactions, neuroscience is incapable of demonstrating what a person was thinking or planning at the time of the alleged tort. 134 This historical problem-i.e. the inability of neuroimaging to provide information about brain activity retrospectivelydoes not mean that neuroscience is useless in tort law, however. A narrowly circumscribed example is the information gleaned from the studies of informed consent among persons diagnosed with schizophrenia. ${ }^{135}$ Those studies focused on the brain activity of the subjects when confronted with a task at the time of the clinical study. Because all subjects shared the same mental diagnosis, these studies could yield (1) current and prospective insight into the ability of schizophrenics, in general, to understand informed consent as well as (2) retrospective insight into how the subjects, and others similarly situated, may have acted in the past, provided that evidence of schizophrenia existed at the relevant point in time. But here, too, caution is paramount. Any attempt to generalize about a specific

treat neuroimaging evidence used in new and unprecedented ways as novel evidence, thereby making admissibility more problematic).

134 See Greely \& Wagner, supra note 107, at 797. The authors offer a somewhat pessimistic view of the utility of neuroscience data in the legal context:

[T] he best [neuroscience] may be able to do is to say that, based on your current mental condition or state, as shown by the current structure or functioning of your brain, you are more or less likely than average to have had a particular mental state or condition at the time of the relevant event.

Id.; cf. Elizabeth Ford \& Neil Aggarwal, Neuroethics of Functional Neuroimaging in the Courtroom, in NEUROIMAGING IN FORENSIC Psychiatry: From the Clinic to the Courtroom 325, 327 (Joseph R. Simpson ed., 2012) (stating that "neuroscientists can explain the neural processes of behavior, but not the presence of intentionality during a criminal act").

135 See Eyler et al., supra note 113, at 141-43. 
event in the past would require expert extrapolation, which may or may not be admissible in court. ${ }^{136}$

Thus, even from the perspective of a nonscientist, it is clear that neuroimaging is not ready to answer many behavioral questions with certainty. Efforts to use neuroscience for such varied concepts as lie detection, ${ }^{137}$ product marketing, 138 and emotional distress damages 139 are more aspirational than factual at the present time. But this does not mean that neuroscience has no use in the courtroom generally or in tort law specifically. Professor Martha J. Farah has called for a balanced approach to the shortcomings and vulnerabilities of neuroimaging studies. She has pointed to issues in cognitive psychology that neuroimaging studies have in fact been useful in answering. ${ }^{140}$ She notes-as this Article explains more fully in Part IV-that concerns about the accurate statistical analyses of brain imaging data are generally no different than concerns about statistical information in other

136 Researchers have also noted that human brains simply change over time, and an fMRI scan conducted at some point in time after the event under scrutiny (such as a criminal act) does not necessarily allow for a conclusion that the same results would have been seen at the earlier date. Jones et al., supra note 106, ๆ 39.

137 See, e.g., Daniel D. Langleben, Detection of Deception with fMRI: Are We There Yet?, 13 Legal \& CRIMinological Psychol. 1 (2008); Jane Campbell Moriarty, Visions of Deception: Neuroimages and the Search for Truth, 42 AKRON L. REV. 739 (2009); Frederick Schauer, Neuroscience, Lie-detection, and the Law, 14 TRENDS IN COGNITIVE SCI. 101 (2010); Joseph R. Simpson, Functional MRI Lie Detection: Too Good to be True?, 36 J. AM. ACAD. PsychiATRY \& L. 491 (2008).

138 See Maggie Fox, Now Scientists Read Your Mind Better Than You Can, Reuters (June 22, 2010, 5:00 PM), http://www.reuters.com/article/2010/06/22/brain-readingidUSN2214937420100622 (reporting a study showing that fMRI scans predicted consumer choices $75 \%$ of the time, while consumers consciously predicted their behavior only $50 \%$ of the time).

139 See Greely \& Wagner, supra note 107, at 810 (suggesting that such research could become useful in cases involving emotional distress, but noting that the accuracy of current studies in unknown).

140 Martha J. Farah, Brain Images, Babies, and Bathwater: Critiquing Critiques of Functional Neuroimaging, in Special Report: Interpreting Neuroimages: An Introduction to the Technology and Its Limits, Hastings CTR. RPT. S19, S23 (Mar.-Apr. 2014). 
disciplines. ${ }^{141}$ Nevertheless close scrutiny of neuroscience, especially when used in non-scientific disciplines such as the law, remains warranted.

\section{B. Stigma and Stereotypes}

The law is a function of its time and place. Tort law has been especially slow to relinquish older concepts of human behavior, which may contribute to lingering and misleading views of persons with mental disabilities. Public perceptions of mental illness and other mental disorders often contain negative stereotypes, which may include low intelligence, lack of control, and violent behavior. ${ }^{142}$ Such stereotypes have created a legal stigma that is difficult to overcome. In a study published in 1999, the researchers observed that their results "reflect an underlying negative attitude [of the general public] toward persons with mental health problems, an exaggeration of the impairments or 'threat' associated with these disorders, and a startling negativity toward individuals with substance dependence problems."143 Tort law incorporates and perpetuates such stereotypes in subtle and not-so-subtle ways by clinging to legal doctrines such as the bifurcated rule of duty.

Although public education about the realities of mental disabilities is the primary vehicle for correcting negative stereotypes, it is not unreasonable to ask the law to do its part and reject the adherence to negative stereotypes. Neuroscientific evidence of mental conditions could be a step toward correcting inaccurate assumptions and

141 Id. at S24. Professor Farah also cautioned: "As we apply such scrutiny, it is important to distinguish between specific criticisms of particular applications or specific studies and wholesale criticisms of the entire enterprise of functional neuroimaging." Id. at S28.

142 See Bernice A. Pescosolido et al., The Public's View of the Competence, Dangerousness, and Need for Legal Coercion of Persons with Mental Health Problems, 89 AM. J. Pub. Health 1339, 1339 (1999) (noting, among other things, that mental health law in the United States is based on an assumption that "mental disorders may place a person at increased risk of physically harming himself or herself or others").

143 Id. at 1345. 
stereotypes about mental illness. The existing legal decisions are replete with archaic and negative terminology about mentally challenged parties. ${ }^{144}$ Neuroscience is poised to provide courts-and by extension the general public-with more accurate information about mental conditions, thereby leading to more accurate results in individual cases.

One commentator has suggested, however, that allowing mental health evidence in the courtroom could actually perpetuate the stigma associated with mental conditions, rather than erase it. Professor Paul S. Appelbaum has observed:

Diagnoses of mental disorders often are perceived to be less reliable and more subjective than diagnoses of other medical conditions. Symptoms of mental disorders may be seen as reflections of moral weakness or lack of will, and the impact of disorders on functional abilities may not be recognized, or occasionally may be exaggerated. The potential impact and limits of current treatments are not widely understood. Indeed, even the various types of mental health professionals are frequently confused. ${ }^{145}$

These observations raise the question whether tort law should delve into the mental conditions of alleged tortfeasors at all. Would establishing a subjective rule for

144 The language employed in many cases and the Restatements contains extreme terminology, such as referring to a mentally disabled person as a "lunatic," see, e.g., McIntyre v. Sholty, 13 N.E. 239, 240 (Ill. 1887); or "insane," see, e.g., Johnson v. Lambotte, 363 P.2d 165, 166 (Colo. 1961). The Restatement has grouped all mental conditions under the label "mental defectives." See Restatement (SECOND) of ToRTs § 283B cmt. b(3) (1965). Given the age of some of these sources-or the fact that legal doctrines contain similar language, such as the insanity defense in criminal law-some of these terms could be viewed as archaic terminology. But what is not appropriate is that they represent negative stereotypes that have persisted in substantive legal doctrine.

145 Appelbaum, supra note 112, at 821 (footnotes omitted). 
mentally challenged adult defendants in negligence actions ingrain in the tort system the notion that all persons with mental conditions lack control, harm others and themselves, or worse? Would the rule erase stigma or increase stigma? This Article has taken the position that more information is superior to mere conjecture and that, on balance, reforming the bifurcated rule to treat mentally disabled adults the same as other adults and children is the better course in the age of neuroscience.

\section{Is Tort Law Ready for Neuroscience?: Revisiting the Policies of the Bifurcated Rule}

Social policy driven rules always represent a balance of various goals, all of which are beneficial but some of which may conflict in particular circumstances. In tort law, which is heavily driven by social policy, courts are forced to decide which goals to favor over the others. In considering the bifurcated rule in relation to neuroscience, it is appropriate at this juncture to revisit the traditional policy justifications for the rule and reconsider that balance. ${ }^{146}$

One policy justification for the bifurcated rule has been that if mentally disabled persons are to "live in the world"i.e. the prevailing social policy in favor of deinstitutionalization - they should compensate those whom they injure. ${ }^{147}$ Those who favor an objective standard for persons with mental disabilities have argued that an objective rule not only protects members of the community but also encourages equal treatment of the mentally

146 In the 20th century, several commentators examined in detail the policies underlying the bifurcated rule and concluded that they are not justified in modern society. See, e.g., Korrell, supra note 8, at 27-46; see also other articles cited supra note 8. Accordingly, this Article will not undertake that level of detailed policy analysis, but instead will add the neuroscience component to the policy discussion.

147 See Creasy v. Rusk, 730 N.E.2d 659, 664 (Ind. 2000) (stating: "It is clear . . . that contemporary public policy has rejected institutionalization and confinement for a 'strong professional consensus in favor of . . community treatment ... and integration into the least restrictive ... environment."'). 
disabled in the community. ${ }^{148}$ There is little proof, however, that tort law's treatment of mentally disabled persons differently from persons with physical disabilities achieves any of the goals of full assimilation into society. ${ }^{149}$ Indeed, a rule that treats the mentally disabled differently from the physically disabled or children identifies them as different and threatens to prolong the stigma and accentuate the negative stereotypes experienced by them.

A second and related policy rationale for the bifurcated rule is the fundamental premise of tort law that the cost of losses should be shifted from the injured party to the person who caused the injury. In many cases, this policy is expressed as the notion that as between two "innocent" parties, the person who caused the injury should pay. A more accurate statement of this policy, and one that is more consistent with tort doctrine, is that the person whose fault caused the injury should pay. The corollary to this statement is that a person incapable of being deemed at fault, whether because of physical or mental disabilities, should not be required to pay for the injury he or she caused. ${ }^{150}$ Although modern tort doctrine incorporates pockets of strict liability, ${ }^{151}$ the broad categories of intentional torts and negligence are firmly fault-based aspects of tort law. The bifurcated rule ignores the fault basis of tort law for a segment of the population.

Third, courts have expressed concern that a subjective rule for persons with mental disabilities would encourage others to feign the symptoms of mental disabilities to escape their own tort liability. This policy rationale may have had some force in an era when psychiatric diagnosis functioned without the assistance of technology. ${ }^{152}$ With the evolution

148 See Stephanie I. Splane, Note, Tort Liability of the Mentally IIl in Negligence Actions, 93 YALE L.J. 153, 163-64 (1983).

149 Korrell, supra note 8, at 40-41.

150 See Holmes, supra note 1, at 109.

151 See, e.g., Dyer v. Maine Drilling \& Blasting, Inc., 984 A.2d 210, 219 (Me. 2009) (strict liability for abnormally dangerous activities); Burley v. Kytec Innovative Sports Equip., Inc., 737 N.W.2d 397, 408-09 (S.D. 2007) (strict liability for a product manufacturing defect).

152 See generally ANDREASEN \& BLACK, supra note 104, at 7-19 (providing a brief history of scientific psychiatry). 
of technologies that examine the brain both structurally and functionally and that may be used as diagnostic tools to identify functional impairments in the brain, the possibility of widespread fabrication of symptoms is diminished, though not eliminated.

Fourth, as the Second Restatement stated, courts continue to disregard the mental disabilities of adult tort defendants because of the courts' own difficulties distinguishing clinical mental conditions from "variations in temperament, intellect, and emotional balance." 153 This concern is coupled with a concern for the "unsatisfactory character of the evidence of mental deficiency in many cases" which could lead to inaccuracies. ${ }^{154}$ In contrast, courts do not express the same concerns about distinguishing variations in physical abilities. Modern developments in mental diagnosis and functional neuroimaging are making this distinction increasingly difficult to sustain for mental disabilities. Indeed, one value of using functional neuroimaging in conjunction with traditional psychiatric diagnosis may be to achieve more accurate diagnoses and treatments and greater predictability of behavioral abnormalities. 155

Finally, the Restatement has expressed strong concern that abrogating the bifurcated rule will lead to relief from liability for all mentally disabled adults as a matter of law, creating an inequity between physically and mentally disabled persons. The Third Restatement articulates this rationale:

[T]o recognize mental disability as a factor bearing on findings of negligence would be onesided in a way that recognizing physical disability is not. ... [W] [Wen the disability is mental or emotional, the disability directly affects the person's rationality and judgment; because of this, it frequently will be the case

153 Restatement (SECOND) OF TORTs $§ 283 \mathrm{~B} \mathrm{cmt}$. b(1) (1965).

154 Id. cmt. b(2).

155 See ANDREASEN \& BLACK, supra note 104, at 116. 
that the law cannot expect the person wisely and appropriately to moderate conduct choices so as to take the person's disability into account. Therefore, in mental-disability cases the law is often unable to implement the balanced approach that it applies to problems of physical disability. ${ }^{156}$

It is inescapable that application of a subjective rule of duty to mentally disabled persons would result in non-liability more often than use of the same rule for physically disabled persons. The Restatement correctly postulates that to the extent that a proven mental disability interferes with the person's ability to make a reasoned choice to act, he or she would likely not be liable under a subjective rule. This Article argues that accepting this result is preferable to the current practice of imposing a version of strict liability on mentally disabled adults by ignoring their mental conditions in negligence cases.

Implicit in the Restatement's comment is the concern that use of a subjective rule would lead to a doctrinal change-a lesser duty of care for mentally challenged persons that would evolve into an absolute defense upon the mere proof of the mental condition. This feared doctrinal shift is not inevitable, however. In the context of physical disabilities, the Third Restatement emphasizes that only "significant and objectively verifiable" conditions would warrant consideration in the duty analysis. Minor conditions would not be taken into consideration. ${ }^{157}$ The

156 Restatement (Third) OF ToRts: Liab. FOR Physical AND EMOTIONAL HARM $§ 11 \mathrm{cmt}$. e (2010).

157 Comment a provides:

The physical disabilities this Section takes into account generally need to be significant and objectively verifiable. For reasons relating to convenience of administration, it is not worthwhile to attempt to take into account disabilities that are minor or not susceptible to objective verification. Thus, a person's claim of being born clumsy would not be regarded as relevant.

Id. cmt. a. 
Restatement also emphasizes that "physical disability is neither a 'justification' nor an 'excuse' for what is otherwise negligent conduct," but rather "an actor's significant physical disability should be taken into account in determining whether the actor's conduct lacks reasonable care." 158 These same qualifications could and should be applied to mental disabilities. With neuroscientific evidence, greater accuracy of diagnosis and understanding of the behavioral implications of a mental condition would become available. Accordingly, what is "significant and objectively verifiable" is a standard that could be met with appropriate evidence.

Thus, the policies advanced in favor of the bifurcated rule do not fully hold up in the era of neuroscience. Reforming the bifurcated rule also requires an understanding of the limitations of the evidence-both how it can assist and what it cannot show. The next Part addresses the challenges of using neuroscientific information as evidence in a tort action.

\section{THE EVIDENTIARY CHALLENGES OF APPLYING NEUROSCIENCE TO TORT LAW}

Courts are in the process of expanding their understanding of the mental health and neuroscience evidence presented to them in all types of cases. One indication of this transformation is that both subject areas have been included in the third edition of the Reference Manual on Scientific Evidence published by the Federal Judicial Center and the National Research Council of the National Academies. 159 Still, common sense cautions against allowing the "wow factor" of neuroscience-a series of state-of-the-art technologies with the ability to dazzle courts and juries with colorful images and exciting information-to overtake the legal system. ${ }^{160}$ Undeniably,

158 Id. at cmt. b.

159 See Appelbaum, supra note 112; Greely \& Wagner, supra note 107.

160 See Michael S. GazZaniga, Who's In Charge: Free Will and THE SCIENCE OF THE BRAIN 190 (2011) ("Many neuroscientists worry 
developing an effective interface between the systems of law and science is not an easy task. Nevertheless, it is not an impossible task if undertaken incrementally and for constructive reasons, not simply for the sake of seizing the next new idea. If the law proceeds with caution, neuroscience-just as any other area of scientific or technological endeavor-offers great promise for resolving issues in tort law. ${ }^{161}$

\section{A. The Intersection of Law and Science}

The integration of science into legal doctrine has been slow to develop because of the seeming incongruity of the two disciplines. Science is process based, while the law demands finality. Incorporating neuroscientific developments into substantive tort law to explain human behavior necessarily requires an overlay of normative judgments on the ever-evolving background of scientific knowledge and theories. ${ }^{162}$ The U.S. Supreme Court has said that "it would be unreasonable to conclude that the subject of scientific testimony must be 'known' to a certainty; arguably, there are no certainties in science." 163 Science in general, and the scientific method in particular, constitutes "a process for proposing and refining theoretical explanations about the world that are subject to further

that a scientist who walks into a courtroom, shows a series of brain scans, and says this is why the defendant shouldn't be held responsible, is overly influential."); Ford \& Aggarwal, supra note 134, at 332.

161 Professor Martha J. Farah has recently reviewed some of the critiques of the broad use of neuroscience, including those that argue that neuroscience evidence is "overly convincing" and "overly appealing." She concluded that "[n]one of the criticisms reviewed here constitute reasons to reject or even drastically curtail the use of neuroimaging." Farah, supra note 140, at S28; see also Morse, supra note 124, at 345 ("For now, however, the potential of undue influence of images does not seem sufficient to weigh strongly against admissibility.").

162 See generally Goodenough \& Prehn, supra note 130, at 1710-13 (discussing the philosophical and historical basis of normative thinking in the law).

163 Daubert v. Merrell Dow Pharms., Inc., 509 U.S. 579, 590 (1993). 
testing and refinement." 164 Accordingly, scientific investigation is progressive, and scientific fact is not finite fact, even when consensus is reached. In the words of the Supreme Court, "[s]cientific conclusions are subject to perpetual revision." 165 As tort law examines human behavior to determine which behaviors are outside the bounds of acceptable norms, thereby leading to tort liability, there is no current consensus about the precise relationship between the structure and function of the brain and normative choices. ${ }^{166}$ But that does not mean that the brain could not or should not enter the legal conversation.

As previously stated, the law accepts the premise that a person's choices of action are driven by multiple factors, some of which may be due to neural connections and others that are influenced by genes expressing themselves during a person's lifetime or by the cumulative impact of an individual's experiences. Thus, mere diagnosis of a mental disorder will never be sufficient without biological, experiential, and circumstantial context. Layered over these factors are legal norms. Courts, and the experts offering evidence, will continue to have difficulty correlating functional imaging findings with actual functional impairment. Information about a person's brain may help to explain the person's actions, but it does not answer the legal question of liability. ${ }^{167}$ That is the domain of tort law and its varied rules.

\section{B. Neuroethics and the Search for Truth in the Courtroom}

This Article has addressed the question whether the existing bifurcated tort rule should be changed. Even

$164 I d$. (quoting the Brief for the American Association for the Advancement of Science et al. as Amici Curiae at 7-8).

165 Id. at 597.

166 See Goodenough \& Prehn, supra note 130, at 1717; Stephen J. Morse, Brain Overclaim Syndrome and Criminal Responsibility: A Diagnostic Note, 3 OHIO ST. J. CRIM. L. 397, 405 (2006).

167 See Michael S. Gazzaniga, The Ethical Brain 89-90 (2005) (stating that "ultimately we must realize that even if the cause of an act (criminal or otherwise) is explainable in terms of brain function, this does not mean that the person who carries out the act is exculpable"). 
assuming that the brain will eventually be found to explain all human behavior, neuroethicists have stressed the need for legal institutions to use that information in an ethical way. ${ }^{168}$ If there is such a concept as neurological determinism, it does not follow that legal determinism or absolute legal rules would or should ensue.169 As neuroscience moves closer to explaining all human perception and behavior in biological terms, it is nevertheless unlikely that the law will relinquish notions of the "self" or the "mind"-in other words human reason and choice. ${ }^{170}$ Tort law is firmly wedded to the latter concepts.

The ways in which neuroscience could be used and abused in the legal system are no different from the ways other types of technological and expert evidence may be used and misused. Does this mean the legal system should place an absolute bar on neuroscience? This is essentially a moot question because "the genie is already out of the bottle" due to the extensive exposure developments in neuroscience have received beyond the medical

168 Martha J. Farah, Neuroethics: The Practical and the Philosophical, 9 TRENDS IN CoGNITIVE SCI. 34, 38-39 (2005), available at http://dx.doi.org/10.1016/j.tics.2004.12.001.

169 See GAZZANIGA, supra note 167, at 101.

170 See Morse, supra note 127, at 841. Professor Morse observed:

For the foreseeable future, . . . the law will be based on the folk-psychological model of the person and behavior . ... Until and unless scientific discoveries convince us that our view of ourselves is radically wrong, the basic explanatory apparatus of folk psychology will remain central. It is vital that we not lose sight of this model lest we fall into confusion when various claims based on neuroscience are made.

Id. Some commentators have stated that neuroscience is not incompatible with the notion of free will, but rather will lead to a different understanding of the relationship between the neuroscientific view of the brain and traditional notions of intuition and legal responsibility. See, e.g., Adina Roskies, Neuroscientific Challenges to Free Will and Responsibility, 10 TRends In Cognitive ScI. 419, 423 (2006); cf. Read Montague, How is Neuroscience Likely to Impact Law in the Near Future?, in A JudGE's GuIde to NeuRoscience: A ConCISE InTRODUCTION 60, 61 (Law and Neuroscience Project \& SAGE Ctr. for the Study of the Mind eds., 2011) (stating that the gap between cognitive variables and fMRI data is "a crucially underdeveloped area of human neuroscience"). 
community. ${ }^{171}$ Professor Martha J. Farah has summed up society's dilemma, stating that the influx of neuroscience information may forge "a more understanding and humane society, as people's behavior is seen as part of the larger picture of causal forces surrounding them and acting through them. But it could also reduce us to machines in each other's eyes, mere clockwork devoid of moral agency and moral value." 172 Tort law already involves traditional ethical notions of responsibility and fairness, ${ }^{173}$ making tort law well-positioned to address the need for balance between the organic bases of human behavioral choices and the traditional notions of self and the mind. ${ }^{174}$

171 See Martha J. Farah, Neuroscience and Neuroethics in the 21st Century, in The Oxford HandBook of Neuroethics (Judy Illes \& Barbara J. Sahakian eds., 2011) 761, 771 (stating that "[a]n across-theboard moratorium on non-medical applications of neuroscience would be unfeasible given that the genie is already out of the bottle").

172 Martha J. FARAH, NeUROethics: AN InTROduction With READINGS 8 (2010).

173 See generally id. at 7 (stating: "It remains to be seen how these developments [in neuroscience] will intersect with our strongly held beliefs about the value of privacy, freedom, fairness, and responsibility. One of the main tasks of neuroethics is to assess the likely impact of neuroscience on these and other moral and cultural ideals.").

174 The classic example of balancing notions of responsibility against potential adverse outcomes in negligence law was stated by Judge Learned Hand in United States v. Carroll Towing, 159 F.2d 169, 173 (2d Cir. 1947), in which he set forth his famous balancing test for liability, which "depends upon whether B [the burden of taking precautions] is less than L [the injury] multiplied by $\mathrm{P}$ [the probability of L occurring]: i.e., whether B less than PL." Professor Morse has discussed the need for balance in relation to criminal law:

In general, the hope is that over time there will be feedback between the folk-psychological criteria and the neuroscientific data. Each might inform the other. Conceptual work on mental states might suggest new neuroscientific studies, for example, and the neuroscientific studies might help refine the folkpsychological categories. The ultimate goal would be a reflective, conceptual-empirical equilibrium.

Morse, supra note 127, at 857. 


\section{Is Neuroscience Ready for Tort Law?: Moving from the Laboratory to the Courtroom}

The short answer to this question is that courts are not yet ready for a wholesale barrage of neuroimaging and other neuroscience evidence. Numerous commentators, both scientists and legal analysts, have expressed this same view. ${ }^{175}$ This opinion is not just a function of the limitations of neuroscientific data interpretation, but reflects the realities of legal evidence in the courtroom. American courts require that expert evidence, of whatever type, be both reliable and relevant to be admissible. These requirements, regardless of the legal test that applies, are quite rigorous. In the federal courts and other jurisdictions ${ }^{176}$ that follow the rule of Daubert v. Merrell Dow Pharmaceuticals, Inc. ${ }^{177}$ and its progeny, ${ }^{178}$ technological evidence such as neuroscience must be held reliable under a flexible multi-factored test: whether the technique has been tested, presumably through replication under the rubric of the scientific method; whether the study has been published or otherwise peer reviewed; the known rate of error of the technique; and whether the methodology has been generally accepted in its field. ${ }^{179}$ Although

175 See, e.g., Jones et al., supra note 106, ๆ 47; Stephen J. Morse, The Future of Neuroscientific Evidence, in THE FUTURE OF EvidENCE 137, 142 (Carol Henderson \& Jules Epstein eds., 2011); Marcus Raichle, What is an fMRI?, in A JUDGE'S GUIDE TO NEUROSCIENCE: A CONCISE InTRODUCTION 5, 12 (Law and Neuroscience Project \& SAGE Ctr. for the Study of the Mind eds., 2011).

176 See, e.g., E.I. du Pont de Nemours \& Co. v. Robinson, 923 S.W.2d 549 (Tex. 1995).

177509 U.S. 579 (1993).

178 See Kumho Tire Co. v. Carmichael, 526 U.S. 137 (1999) (applying the Federal Rules of Evidence and Daubert to all types of expert evidence); Gen. Elec. Co. v. Joiner, 522 U.S. 136 (1997) (explaining the relevancy arm of the Daubert test).

179 The flexible Daubert rule has been codified in the Federal Rules of Evidence, which provide:

A witness who is qualified as an expert by knowledge, skill, experience, training, or education may testify in the form of an opinion or otherwise if: 
reliability is based on scientific knowledge, the U.S. Supreme Court has said that the subject of the expert's testimony need not be known to a certainty. ${ }^{180}$ Other jurisdictions espouse the older Frye rule of reliability, requiring more rigidly that the technique must be generally accepted in the relevant field.181 Under either test, reliability is a stringent standard. 182

The expert evidence must also be legally relevant. As the Federal Rules of Evidence set forth, even evidence otherwise deemed relevant may be excluded if "its probative value is substantially outweighed by a danger of . . . unfair prejudice, confusing the issues, [or] misleading the jury." 183 The Supreme Court addressed relevance in the context of expert scientific evidence in General Electric Company v. Joiner, ${ }^{184}$ in which the Court stressed that the expert's opinion must provide a close "fit" to the specific issues in the

(a) the expert's scientific, technical, or other specialized knowledge will help the trier of fact to understand the evidence or to determine a fact in issue;

(b) the testimony is based on sufficient facts or data;

(c) the testimony is the product of reliable principles and methods; and

(d) the expert has reliably applied the principles and methods to the facts of the case.

Fed. R. Evid. 702. The advisory committee note adds several factors to this test, including, among other factors: (1) whether the evidence was developed for the specific litigation for which it was offered; (2) whether too much of an analytical gap exists between the data and the expert's conclusion; and (3) whether the expert considered other theories. Fed. R. Evid. 702 advisory committee's note.

180 Daubert, 509 U.S at 590.

181 See Frye v. United States, 293 F. 1013, 1014 (D.C. Cir. 1923). Some states continue to follow the Frye rule. See, e.g., Slay v. Keller Indus., Inc., 823 So.2d 623 (Ala. 2001); People v. Leahy, 882 P.2d 321 (Cal. 1994); Blackwell v. Wyeth, 971 A.2d 235 (Md. 2009); Goeb v. Tharaldson, 615 N.W.2d 800 (Minn. 2000).

182 See Jean Macchiaroli Eggen, Clinical Medical Evidence of Causation in Toxic Tort Cases: Into the Crucible of Daubert, 38 Hous. L. REV. 369, 375-88 (2001) (discussing Daubert and its progeny); Jean Macchiaroli Eggen, Toxic Torts, Causation, and Scientific Evidence After Daubert, 55 U. PITT. L. REv. 889, 909-31 (1994) (discussing Frye and Daubert).

183 Fed. R. Evid. 403.

184522 U.S. 136 (1997). 
case. Acknowledging that experts necessarily must extrapolate from data, the Court issued a warning that the expert evidence will be inadmissible if it "is connected to existing data only by the ipse dixit of the expert." 185 When the "analytical gap" between the data and the expert's conclusions is too great, the evidence will not be allowed. ${ }^{186}$ Thus, relevance is not met by merely offering reliable evidence that relates to an issue in the case. The standard is much higher, requiring a direct nexus between the underlying data and the expert's conclusion and then again between the conclusion and the narrow issue for which it is offered.

Turning to mental disabilities in tort law, all expert neuroscience evidence offered in support of the positions of the parties to the lawsuit must satisfy the reliability and relevance standards, or it will not see the light of day in the courtroom. These requirements are no different from those applied to any other expert evidence offered in support of an issue in a tort case. ${ }^{187}$ What exactly does the law expect from neuroscience? This Article proposes that the law should expect nothing more from neuroscience than it expects in any case involving expert evidence. To that extent, courts should be open to the introduction of neuroscience evidence. That neuroscience is an emerging technology is no reason to view it as less promising and potentially informative than other types of newer

$185 I d$. at 146. An expert may rely on studies generated by others if the studies are the type reasonably relied upon in the field. Fed. R. Evid. 703.

186 Joiner, 522 U.S. at 146 . In Joiner, the analytical gap was too great and the evidence had properly been excluded by the trial court. See id. at 145-46; see also O'Conner v. Commonwealth Edison Co., 13 F.3d 1090, 1106-07 (7th Cir. 1994) (excluding expert testimony that radiation was the cause of the plaintiff's cataracts because the opinion was merely subjective and did not have a sufficient scientific basis); Chikovsky v. Ortho Pharmaceutical Corp., 832 F. Supp. 341, 346 (S.D. Fla. 1993) (excluding expert testimony that the mother's use of an acne medication caused the plaintiff's birth defects because the opinion relied on studies conducted on a drug similar, but not identical, to the drug involved in the case).

187 Kumho Tire Co. v. Carmichael, 526 U.S. 137, 147-48 (1999) 
technologies, such as DNA analysis. ${ }^{188}$ Nevertheless, courts should be attuned to the substantive difference in what is actually known from neuroscience and what the parties merely hope neuroscience can show.

From an evidentiary perspective neuroscience evidence will face some formidable challenges in individual cases regardless of the evidentiary standard applicable in the specific jurisdiction. ${ }^{189}$ Neuroscience evidence may be loosely categorized as generalized or specific. Generalized evidence may be illustrated by hypothesizing a diagnosed mental condition, such as schizophrenia. ${ }^{190}$ A diagnosis of schizophrenia in the defendant may provide sufficient information to allow an expert to state that a correlation exists between diagnosed schizophrenics and the type of behavior in issue in the case. ${ }^{191}$ But this information, without more, does not provide a specific causal connection between the diagnosed mental condition and the behavior of the defendant at the time of the tortious act. In addition to generalized evidence, the party must offer specific evidence, such as structural or functional neuroimaging studies

188 Cf. Daubert, 509 U.S. at 592 n.11 (stating that "well-established propositions are less likely to be challenged than those that are novel, and they are more handily defended"); Greely \& Wagner, supra note 107, at 787 (noting that neuroscience has not yet "undergone the kind of standardization seen, for example, in forensic DNA analysis").

189 See Hon. Jed S. Rakoff, Guilty vs. Guiltiness Responses: Science and the Law: Uncomfortable Bedfellows, 38 SETON HaLL L. REv. 1379, 1392 (2008).

190 Generalized neuroscience evidence-or group data-is the kind of information that captured the attention of the U.S. Supreme Court in juvenile sentencing cases. See, e.g. Alabama v. Miller, 132 S. Ct. 2455, 2464-65 (2012).

191 Professor Farah has suggested that where an observable organic phenomenon exists in a person's brain, we are more likely to associate that phenomenon with behavior. See Farah, supra note 168, at 38. She pointed to the well-known case of Phineas Gage, the railway worker who suffered traumatic brain injury and experienced a personality change. Professor Farah stated that "we are not inclined to blame Phineas Gage for his bad behavior" because of the apparent organic basis. Id. She noted that neuroscience is uncovering "the more subtle and gradual ways" that organic changes in the brain may influence behavior. Id. These will present the law with more difficult challenges. 
conducted on the party herself. Even when such individualized studies indicate a clinical brain condition, the relationship between the condition and the behavior in question in the case will still require complex expert extrapolation.

Moreover, tort cases typically focus intently on subjective and historical issues-what the parties understood at a particular moment in the past. Because many of the studies using functional neuroimaging report the results by group averages, at best these studies provide generalized information about the group. At least at the current stage of neuroscience technology and research, this evidence would result in too large an analytical gap for the evidence to be admissible without additional specific evidence. Still, these averaged group studies could be a useful starting point for specific individuals or may provide more acceptable information in combination with a variety of other more individualized psychiatric or neurological evidence. How the experts interpret the information and apply it to the issues of a particular tort case must then pass legal muster under the rules of evidence for reliability and relevance.

To date, proponents of neuroimaging studies have had difficulty meeting evidentiary standards. ${ }^{192}$ Difficult evidentiary issues should not, by themselves, prohibit neuroscience from being used in the courtroom. Courts have no rational basis for rejecting evidence of mental disabilities simply because the issues are complex or because the fact questions present administrative difficulties. On the other hand, courts must subject neuroscience evidence to the same systematic scrutiny that applies to other expert evidence and should resist being lured by the excitement of what it promises. The next Part

192 See, e.g., United States v. Semrau, No. 07-10074 MI/P, 2010 WL 6845092 (W.D. Tenn. June 1, 2010). In Semrau, the magistrate judge discussed at length fMRI evidence, proffered on the issue of veracity, in relation to the Daubert test, concluding that "[a]lthough [the expert] is qualified to offer an opinion, the court nevertheless concludes that his testimony should be excluded because, at least at this early stage in its development, fMRI based lie detection does not satisfy the requirements of Rule 702." Id. at *10. 
proposes a cautionary way to begin the discourse about envisioning a constructive role for neuroscience in the longoverdue reformation of the bifurcated rule.

\section{A MODEST PROPOSAL WITH CAVEATS}

In an earlier article, Eric J. Laury and I proposed a broad process-based model for involving neuroscience in tort law. ${ }^{193}$ Our proposal served as a kind of prolegomena to a fuller process of integrating information obtained from neuroscience, and neuroimaging in particular, into tort doctrine. It was based on the notion that a better understanding of the brain can help us to determine the validity of the premises on which tort doctrine is based. The proposal was "sufficiently broad and flexible to accommodate both the rapidly evolving science and tort law's resistance to change." 194 As the technologies grow in reliability and inform the issues frequently raised in tort cases, neuroscience may add a valuable dimension to tort issues and help to shape tort doctrine in the future. This Article begins the process of applying that model.

For the model to be effectively implemented, neuroscience must be introduced in tort cases incrementally on an issue-by-issue basis. This task presupposes identifying a doctrinal issue that needs correcting, supplementing, or reforming. The bifurcated negligence rule of physical and mental disabilities is just such an issue. Accordingly, this rule may provide an effective doctrinal "laboratory" for using the neuroscience to reform an aspect of tort law that is outmoded. This issue is a logical and appropriate place to begin the analysis for several reasons. First, the essence of the bifurcated rule is disparate treatment of adults with mental disabilities, which directly implicates neuroscience. Indeed, some techniques and theories related to the organic basis of mental conditions and symptomatology already have wide acceptance in the neuroscience and psychiatric communities and are regularly

193 See Eggen \& Laury, supra note 9, at 284-86.

194 Id. at 284. 
used in the courts. Second, most of the policies asserted to justify the bifurcated rule no longer hold up in an era in which more detailed information is known about mental diagnoses and about brain structure and function. ${ }^{195}$ Third, the bifurcated rule has perennially been the subject of much criticism over the years, even before neuroscience began to make inroads into the law, 196 and neuroscience can serve as the tipping point to finally abrogate the objective rule for mentally disabled adults.

\section{A. A Framework for Commencing the Discourse}

With these matters in mind, this Article proposes the following modest framework for employing neuroscience to reform the bifurcated rule in tort doctrine.

\section{The duty rule for adults with mental disabilities} should be consistent with the rule for physical disabilities.

The bifurcated rule should be replaced with a single subjective duty rule for adults with disabilities, whether physical or mental. A single rule would not only establish a single duty standard for adults with disabilities in negligence actions. It would also bring negligence law into agreement with intentional torts on matters related to mental disabilities and would be consistent with the negligence standard for children.

2. The unified subjective rule should expressly recognize that many mental disabilities are organic in nature.

The Third Restatement explicitly recognized that "many mental disabilities have organic causes," but opted to retain the traditional bifurcated rule for policy reasons, including administrative convenience. ${ }^{197}$ Those mental disabilities without currently known organic causes will not necessarily

195 See supra notes 146-58 and accompanying text.

196 See articles cited supra note 8.

197 Restatement (ThiRd) Of Torts: Liab. For Physical And EMOTIONAL HARM $§ 11$ cmt. e (2010). 
be excluded from consideration in a negligence case under the unified subjective rule, though it may be more difficult for the party to establish the existence of the disability. Recognizing the organic basis of mental disabilities, courts would no longer be required to place certain mental conditions on one side or the other of an artificial line between physical and mental. For example, old age dementia, whether resulting from a vascular condition, Alzheimer's, or an unknown operation of the aging process on the brain would be considered a disability and treated the same.

3. To be considered in determining liability, the mental disability must be "significant and objectively verifiable."198

This limitation would eliminate minor variations in temperament from being considered, and would require proof of the disability. Structural and functional neuroimaging, if available, would be allowable, provided that the proof is independently admissible under the rules of evidence. The requirement that the disability be "significant and objectively verifiable" is already the standard for physical disabilities. ${ }^{199}$ This proposal does not limit the rule to "organic disabilities" because of concern that such a rule would be underinclusive. Some "significant and objectively verifiable" mental disabilities may not be detectable as organic changes in the brain or other bodily organs. Thus, this proposal would not require neuroscience evidence as a prerequisite; rather, other types of psychiatric evidence and other clinical medical evidence may be sufficient in some cases.

4. All expert evidence of mental disabilities, including all neuroscience evidence, will be subject to the applicable rules of evidence.

198 Id. § $11 \mathrm{cmt}$. a (2010) (discussing physical disabilities only).

199 Id. 
Neuroscience evidence should be treated the same as any other scientific, technological, or other expert evidence. It should not be held to a higher standard for admissibility, nor should it be held to a lesser standard because of its novelty. Accordingly, any neuroscience evidence and other evidence offered to prove the mental disability and its causal relevance to the tort would be required to meet the applicable evidentiary standards in the jurisdiction, whether that standard conforms to Daubert, Frye, or a hybrid rule.

\section{There should be no new defense for persons with} mental disabilities.

In this Article, the concepts of intent in intentional torts and duty/breach in negligence law have been singled out as specific elements that could benefit from emerging information obtained from neuroscience. This Article does not suggest that a legal defense should be created that would relieve a mentally disabled defendant of liability for his or her conduct in the same sense as the insanity defense operates in criminal law. No new defense should be created where one did not exist for persons with physical disabilities. $^{200}$

6. Existing privileges and defenses that involve mental conditions should remain in effect.

Thus, in an intentional tort action in which the defendant asserts the privilege of consent, a plaintiff asserting that he or she did not consent because of lack of capacity due to a mental disability would still be required to demonstrate both the existence of the incapacity and that the defendant knew of the incapacity. In jurisdictions such as Wisconsin, where sudden mental incapacitation is recognized as a defense to a negligence claim according to

200 The Third Restatement states: "Under this Section, physical disability is neither a 'justification' nor an 'excuse' for what is otherwise negligent conduct." Id. at cmt. b. 
the same rules as sudden physical incapacitation ${ }^{201}$-i.e. proof of the incapacitation along with lack of foreseeability-no change in the applicable rules would occur for this narrow set of circumstances.

\section{B. Some Caveats}

This Article has emphasized the need for caution in moving toward a beneficial amalgamation of neuroscience and tort law. Neuroscience is not a talisman that provides an immediate answer to all human behavioral questions. And it will never, by itself, provide definitive answers to the normative questions inherent in tort law. The proposal in this Article demonstrates that neuroscience has much to contribute to tort law, however, both in resolving individual cases and reforming an anachronistic tort doctrine to reflect contemporary knowledge and values. Two broad caveats accompany this cautionary approach.

\section{Courts should be cognizant of the limitations of the} technology.

This Article has mentioned only a few of the technical limitations of neuroimaging that may impact tort law, and others exist. ${ }^{202}$ In general, and for the foreseeable future, neuroimaging is interpretive. ${ }^{203}$ It will continue to progress and improve in sophistication, accuracy, and interpretive consistency, and as it does so it will become more useful in tort cases. Hardware, software, statistical programs, and the human factor-involving both the researchers and the subjects-will continue to create challenges to

201 Breunig v. Am. Family Ins. Co., 173 N.W.2d 619, 622 (Wis. 1970).

202 See supra notes 124-36 and accompanying text. For a brief summary of many of these technical limitations from the perspective of a lawyer, see Morse, supra note 124, at 343-45.

203 See Brown \& Murphy, supra note 128, at 1162-63 (stating that "we are at present a considerable distance away from the precise mapping of complex mental state onto unique brain activation patterns"). 
understanding and using the data that are compiled. Determining what is "normal" or "abnormal" is a complex matter of interpretation of the data. ${ }^{204}$ Translating those data into a legal standard, such as "reasonableness" or "intent," is even more difficult.

2. Courts should take care to apply the same evidentiary scrutiny to neuroscientific evidence as to other expert evidence, no more and no less.

As neuroscience moves into the courtroom, the transition will not be smooth. For scientists, observations and conclusions depend solely on the validity of the methodology. ${ }^{205}$ In contrast, the law asks experts to extrapolate from their observations to answer normative questions generated by the law applicable to the particular case. Instead of viewing this as a disconnect that is unresolvable, lawmakers and neuroscientists should come together for a closer understanding of what is scientifically known and unknown and the ways that science can inform the law. ${ }^{206}$ That process has already begun. Should the law

204 See Grafton, supra note 6, at 57.

205 See DAvid L. FAigman ET AL., 1 Modern Scientific Evidence: The LAW AND SCIENCE OF EXPERT TESTIMONY § 4:2, at 137 (2005-2006). The scientists' view may be stated as follows:

To real scientists a finding of fact is only as good as the methods used to find it. Scientific method is the logic by which the observations are made. Well designed methods permit observations that lead to valid, useful, informative answers to the questions that had been framed by the researcher. For scientists, the key word in the phrase "scientific method" is method. Methodology_the logic of research design, measures, and procedures-is the engine that generates knowledge that is scientific.

Id. Lawyers, by contrast, ask a different set of questions. The fit between the product of scientific inquiry and the product of legal inquiry, particularly in the courtroom, is not a close or natural one. Rather, it is forced and artificial. Yet the system must find a way to accommodate both approaches.

206 Commentators have been quick to remind us that it was not all that long ago that phrenology - the study of the anatomical terrain of the human skull-was believed to provide answers to the sources of 
remain stagnant while science progresses? This epistemological question is intrinsic to any effort to use science to shape the law. As the courts attempt to resolve this tension, many evidentiary challenges will arise. Courts should be vigilant in applying admissibility standards, recognizing that there is no precise method for translating scientific knowledge into legal certainty or factual truth in the courtroom.

\section{CONCLUSION}

Neuroscience has the potential to be a tsunami wave that will soon bear down upon the courts with copious amounts of data and no dearth of opinions about what the data mean. Should tort law run from it or face it head-on? Neuroscience will only become more prevalent and more sophisticated, not less so. The law should be prepared to address the relentless advance of new techniques, theories, and philosophical questions that neuroscience brings with it. Although neuroscience may be considered an emerging field, tort law has much to gain from what neuroscience has to offer. This is most true when considering the ways in which tort doctrine treats alleged adult tortfeasors who are mentally disabled. In negligence law, the traditional bifurcated rule of duty-which refuses to consider the mental disabilities of adults in negligence actions but considers physical disabilities-has remained virtually unchanged for centuries and is based upon outmoded assumptions and negative stereotypes. This rule is a logical place to begin a reasoned discourse about how new developments in neuroscience can play a role in reforming

human behavior. See Stacey A. Tovino, Imaging Body Structure and Mapping Brain Function: A Historical Approach, 33 AM. J.L. \& MED. 193, 195-207 (2007). Some might argue that phrenology was a direct precursor to what we consider the new neuroscience. See id. at 207 ("Although phrenology ultimately failed as a science, it left behind a formalized concept of cerebral localization and the idea that science, perhaps a science not too different from the pseudoscience of phrenology, could be used to investigate the functions of different regions of the brain." (footnote omitted)). 
tort doctrine to meet the realities of the twenty-first century. 